\title{
Mono- and Dinuclear Copper(II) Complexes of Pendant-Arm Macrocyclic Polyamines: Synthesis, Characterization and Investigation as Hydrolytic Cleavage Agents for DNA
}

\author{
NICHOLA MCCANN ${ }^{a}$, GEOFFRY N. DE IULIIS ${ }^{a}$, GEOFFREY A. LAWRANCE ${ }^{a^{*}}$, \\ MARCEL MAEDER ${ }^{a}, \operatorname{KAREN~SCHRADER~}^{a}$ AND PETER MOORE $^{b}$ \\ "Discipline of Chemistry, School of Envirommental and Life Sciences, The University of Newcastle, Callaghan, N.S.W. 2308, Australia \\ ${ }^{b}$ Department of Chemistry; The University of Wanwick, Coventry CV4 7AL, UK'
}

Received on November 10, 2005; in final form April 28, 2006.

\begin{abstract}
Based on the 10-methyl-1,4,8,12-tetraazacyclopentadecane-10-amine (1) parent, macrocycles 10-benzylamine-10-methyl-1,4,8,12-tetraazacyclopentadecane (2), 10-(2'pyridinylmethanamino)-10-methyl-1,4,8,12-tetraazacyclopentadecane (3) and 5(hydroxymethyl)-5'-(10"-methyl-1",4",8",12"-tetraazacyclopentadecane-10"-amino)-(2,2'dipyridine) (4), as well as the $p$-xylene-linked dinucleating macrocycle 1,4-bis(10'methyl-1', $4^{\prime}, 8^{\prime}, 12^{\prime}$-tetraazacyclopentacecane-10'-aminomethyl)benzene (5) and its $o$ xylene analogue (6), have been synthesized as free ligands and or copper(II) complexes and characterized spectroscopically. Cyclic voltammetry of the $\mathrm{Cu}$ (II) complexes of $2-6$ are also reported, with involvement of the pendant groups in complexation influencing voltammetric behaviour. Potentiometric titrations of $1,2,5$ and 6 and their $\mathrm{Cu}$ (II) complexes yielded $\mathrm{pK}_{\mathrm{a}}$ values. Both dimers 5 and 6 , as well as their mononuclear close analogues 1 and 2, have proven to be inefficient as hydrolytic cleavage agents for DNA, as was also the case for mononuclear $\mathrm{Cu}$ (II) complexes of $\mathrm{N}_{4}$-macrocycles with a range of $\mathrm{N}$ pendant groups based on the 3,7,11,17-tetraazabicyclo[11.3.1] heptadeca-1(17),13,15triene framework (7). Mononuclear triazamacrocyclic $\mathrm{Cu}(\mathrm{II})$ complexes show greater activity. Of other dinuclear systems examined, dicopper(II) complexes of the relatively rigid compartment ligands 3,13-dimethyl-3,13-dinitro-1,5,11,15-tetraazacycloeicosane8,18-diol and -dithiol are also inactive. Whereas the $1: 1 \mathrm{Cu}(\mathrm{II}): \mathrm{L}$ complexes of cyclam and its $N, N^{\prime}, N^{\prime \prime}, N^{\prime \prime}$-tetrakis(methylbenzyl) substituted analogue are inactive, the tetrakis(2-methylpyridine)-substituted analogue as a $2: 1 \mathrm{Cu}(\mathrm{II}): \mathrm{L}$
\end{abstract}

*Corresponding author: Tel.: +61-2-49215471; fax: +61-2-49215472; E-mail address: Geoffrey.Lawrance@newcastle.edu.au 
species $\mu$-hydroxy (tetrakis(2'-methylpyridine)-1,4,8,11-tetraazacyclotetradecane) dicopper(II) is very efficient as a cleavage agent for plasmid DNA, with both single and double strand cleavage steps observed with rate constants (at $\mathrm{pH} 7.6,37^{\circ} \mathrm{C}, 0.8 \mathrm{mM}$ complex, $0.12 \mathrm{mg} / \mathrm{mL}$ plasmid) of $1.2 \times 10^{-4}$ and $3.5 \times 10^{-6} \mathrm{~s}^{-1}$ respectively. This is attributed to the capacity for concerted binding to the phosphodiester unit and nucleophilic attack by the coordinated hydroxide molecule that is activated by bridging between the two metal centres.

Keywords: Pendant-arm macrocycle, Copper(II), Cyclic voltammetry, Potentiometric titration, DNA. Cleavage kinetics.

\section{INTRODUCTION}

Phosphodiesters are highly resistant to hydrolytic cleavage, yet this process is a basic requirement in natural systems. Hence nature has developed highly efficient systems for catalytic cleavage that are also often site-specific; for example, restriction endonucleases cleave DNA hydrolytically with exceptional sequence specificity and target recognition sites that are as small as four DNA base pairs [1]. Divalent metal ions have an essential role at the catalytic center of nucleases, where two metal ions often lie [2-4]. High-resolution X-ray crystal structures of nucleases bound to DNA as both substrate and product forms have assisted our mechanistic understanding of nucleases [5], where it appears that co-operativity between the metal centres is mechanistically important. Roles for the metal ions involve positioning of both the substrate and nucleophile, and activation of the water nucleophile through coordination [6-8].

With recognition of the key role of metal ions in nucleases, the development of low molecular weight metal complexes as artificial nucleases for hydrolytic cleave of both RNA and DNA has, not surprisingly, attracted growing interest $[2,9,10]$. Of particular concern is the demanding task of initiating rapid and preferably selective DNA cleavage, since potential applications arise should a commercially accessible artificial nuclease that could target specifically a single promoter region in the genome be developed. Both mononuclear and polynuclear complexes have been examined, with a deal of consensus reached on the view that hydrolytic cleavage requires two separate 'active' coordination sites, for the separate tasks of substrate binding and supply of a coordinated nucleophile. The development of dinuclear metal complexes presenting appropriate sites on separate metal centres is one focus for coordination chemists [11], although mononuclear complexes with two available sites are also of interest; for example, the mononuclear copper(II) complex of both the tridentate Schiff base [(2-imidazol-4-yl)ethyl)(1methylimidazol-2-yl)methyl)imine and the aminoalcohol cis,cis,cis-2,4,6-triamino-1,3,5trihydroxycyclohexane promote hydrolytic cleavage of double-strand plasmid DNA under anaerobic and aerobic conditions $[12,13]$, the latter complex being particularly effective. Superiority has been reported for dinuclear compared with mononuclear close analogues; for example, 11,3-bis(1,4,7-triaza-1cyclononyl)propane dicopper(II) cleaves plasmid DNA much better than the mononuclear $(1,4,7$ triazacyclononane)copper(II) ion under identical conditions [14]. In the present study, examination of a number of mononuclear and dinuclear macrocyclic systems of varying rigidity and topologies has been undertaken, providing further information on shape-activity relationships. Further, in leading to this study, the syntheses of a number of new pendant arm and linked macrocyclic polyamines have been developed and characterization of these new systems by a range of physical methods, including potentiometric titrations and cyclic voltammetry, are reported. 

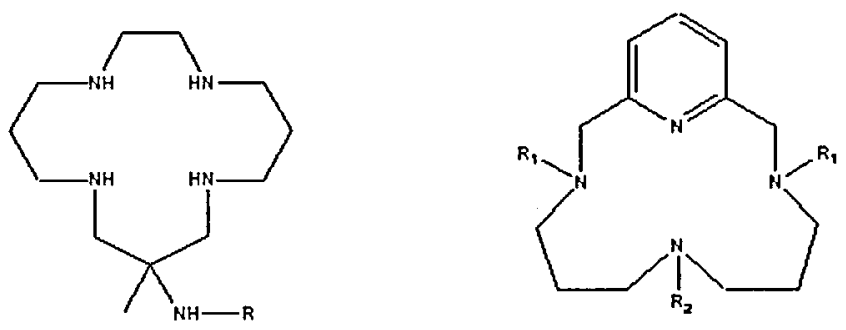

(1) $\mathrm{R}=\mathrm{H}$

(2) $\mathrm{R}=\longleftarrow$

(3) $\mathrm{R}={ }^{\mathrm{N}}$

(4) $\mathrm{R}=$

(5) $\mathrm{R}=$

(6) $\mathrm{R}=ح$

(7) $\quad \mathbf{R}_{\mathbf{l}}=\mathbf{R}_{\mathbf{2}}=\mathrm{H}$

(8) $\mathrm{R}_{1}=\longleftarrow \mathrm{R}_{2}=\mathrm{H}$

(9) $R_{1}=R_{2}=\bigsqcup$

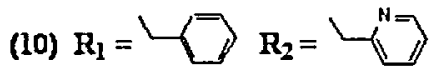

(11) $\mathrm{R}_{1}=\leadsto \mathrm{R}_{2}=\sim_{\mathrm{COOH}}$

(12) $\mathbf{R}_{1}=$ N $\mathbf{R}_{2}=\mathrm{Me}$

(13) $\mathrm{R}_{1}=\sqcup \Longleftrightarrow \mathrm{R}_{2}=\leadsto$

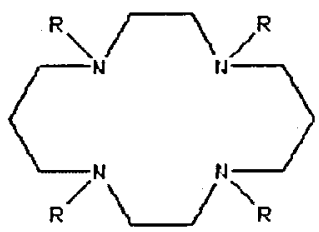

(14) $\mathrm{R}=\mathrm{H}$

(15) $\mathrm{R}=$

(16) $\mathrm{R}=$ N

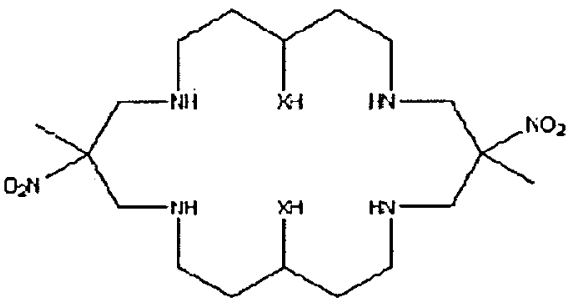

(21) $\mathrm{I}=\mathrm{O}$

(22) $\mathrm{X}=\mathrm{S}$

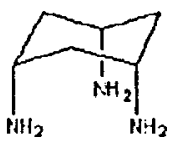

11)

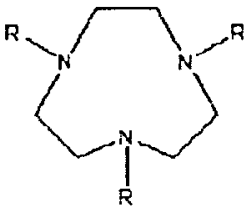

(18) $\mathrm{R}=\mathrm{H}$

(19) $\mathrm{R}-\mathrm{Me}$

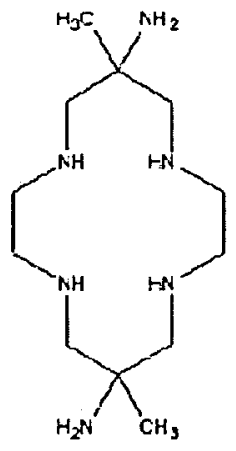

(23)

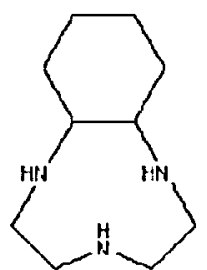

(20)

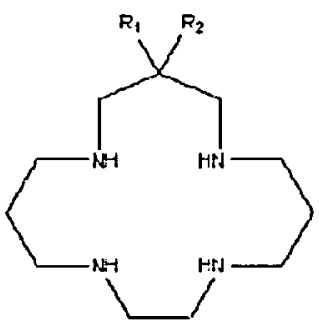

(2t) $\mathrm{R}_{1}=\mathrm{NH}_{2} \mathrm{R}_{2}=\longrightarrow-\mathrm{HH}_{2}$

(25) $R_{1}=R_{2}=H$

(26) $\mathrm{R}_{1}-\mathrm{H} \mathrm{R}_{2}=\mathrm{COOH}$ 


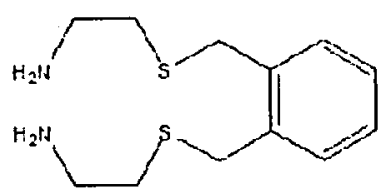

(27)

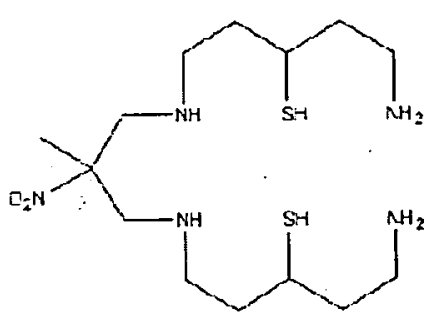

(29)

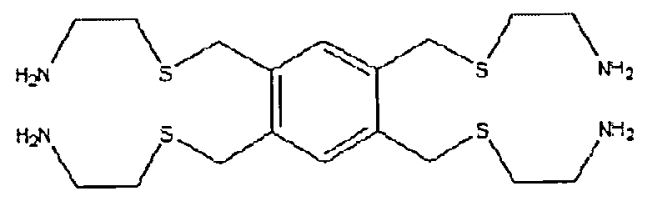

(28)

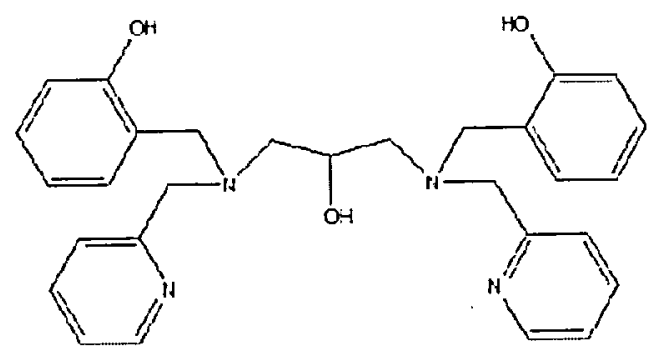

(30)

\section{EXPERIMENTAL}

\section{Syntheses}

\section{0-Methyl-1,4,8,12-tetraazacyclopentadecane -10-amine,}

This ligand was prepared exactly as described, from nitroethane, aqueous formaldehyde and $\left[\mathrm{Cu}\left(\mathrm{N}, \mathrm{N}^{\prime} \text {-bis(3-aminopropyl)ethylenediamine) }\right]^{2+}\right.$ [15]. The product purity was confirmed by elemental analysis and spectroscopic comparison with an authentic sample.

\section{0-(Phenylmethanamino)-10-methyl-1,4,8,12- tetraazacyclopentadecane,}

(1) $5 \mathrm{HCl}(5.0 \mathrm{~g}, 11 \mathrm{mmol})$ was dissolved in 100 $\mathrm{mL}$ water and the $\mathrm{pH}$ adjusted to 6 with $2.5 \mathrm{M} \mathrm{NaOH}$. Ethanol $(900 \mathrm{~mL})$ was added, and the $\mathrm{pH}$ readjusted to $\sim 6 \mathrm{Na}\left[\mathrm{CN}\left(\mathrm{BH}_{3}\right)\right](2.2 \mathrm{~g}, 35 \mathrm{mmol})$ was added followed by benzaldehyde $(1.1 \mathrm{~mL}, 11 \mathrm{mmol})$ and the $\mathrm{pH}$ was readjusted to 6 with $1 \mathrm{M} \mathrm{HCl}$. The $\mathrm{pH}$ was maintained at $\sim 6$ for 7 hours by the dropwise addition of $1 \mathrm{M} \mathrm{HCl}$ as required, and the mixture was left stirring overnight. The $\mathrm{pH}$ of the solution was readjusted to $\sim 12$, and the solvent removed. The solid residue was extracted with chloroform, the chloroform was removed, and the remaining oil dissolved in water and $\mathrm{CuCl}_{2} .2 \mathrm{H}_{2} \mathrm{O}(2.0 \mathrm{~g}, 12 \mathrm{mmol})$ added. The resulting blue solution was diluted and loaded onto a column of SP Sephadex C-25 resin and washed with water. The first blue band was eluted with $0.25 \mathrm{M} \mathrm{NaClO}_{4}$; the remaining band, eluted with $1 \mathrm{M} \mathrm{NaCl}$, proved to be unreacted 1 . Slow evaporation of the first band gave the product as a purple solid. Anal. Calc for $\mathrm{C}_{19} \mathrm{H}_{35} \mathrm{Cl}_{2} \mathrm{CuN}_{5} \mathrm{O}_{8} \cdot 0.5 \mathrm{H}_{2} \mathrm{O}: \mathrm{C}, 37.7 ; \mathrm{H}$, $5.8 ; \mathrm{N}, 11.6$. Found: C, 37.6; H 5.9; N $11.5 \%$. Electronic spectrum (water): $\lambda_{\max } 566 \mathrm{~nm}\left(\varepsilon 136 \mathrm{M}^{-1}\right.$ $\mathrm{cm}^{-1}$ ). IR Spectrum (KBr disc): 3275, 3213, 1597 (NH); 2936, $2875\left(\mathrm{CH}_{2}\right)$; 1449, 746, 701 ( $\left.\mathrm{ArH}\right) ; 1116$, $1087,625\left(\mathrm{ClO}_{4}^{-}\right) \mathrm{cm}^{-1}$. The product was dissolved in water and reloaded onto SP Sephadex resin to permit anion exchange by elution with $0.5 \mathrm{M} \mathrm{NaCl}$. The single band collected was reduced in volume, and the $\mathrm{Cu}$ removed via zinc/acid reduction. The colourless solution was filtered, rotary evaporated to dryness, extracted with chloroform, dried over $\mathrm{MgSO}_{4}$ and the solvent removed. The resulting oil was precipitated as the hydrochloride salt from $3 \mathrm{M} \mathrm{HCl} / \mathrm{ethanol}(0.35 \mathrm{~g}, 6$ \%). Anal. Calc for $\mathrm{C}_{19} \mathrm{H}_{35} \mathrm{~N}_{5} \cdot 5 \mathrm{HCl} \cdot \mathrm{EtOH}: \mathrm{C}, 41.0 ; \mathrm{H}$, $6.9 ; \mathrm{N}, 12.5$. Found: C, 40.65; H 7.2; N $12.5 \%$. ${ }^{1} \mathrm{H}$ NMR $\left(\mathrm{D}_{2} \mathrm{O}\right): \delta 2.18\left(\mathrm{~m}, 2 \mathrm{H},-\mathrm{C}-\mathrm{CH}_{2}-\mathrm{C}-\right), 3.16-3.65$ (m, 16H, - N-CH $2^{-}$), 4.33 (s, 2H, -N-CH $2_{2}-\mathrm{Ar}-$ ), 7.50 (s, 
5H, ArH) ppm. ${ }^{13} \mathrm{C}\left({ }^{1} \mathrm{H}\right.$-decoupled) NMR $\left(\mathrm{D}_{2} \mathrm{O}\right): \delta$ $20.66\left(-\mathrm{CH}_{3}\right), 26.13\left(-\mathrm{C}-\mathrm{CH}_{2}-\mathrm{C}-\right), 44.07,46.79,49.01$ $\left(-\mathrm{N}-\mathrm{CH}_{2}-\mathrm{C}-\mathrm{C}-\mathrm{N}-\right), 48.84$ (tert. C), $56.30\left(-\mathrm{N}-\mathrm{CH}_{2}-\mathrm{C}-\right.$ $\mathrm{N}-), 61.22\left(\mathrm{~N}-\mathrm{CH}_{2}-\mathrm{Ar}\right), 132.41,132.95,132.97$, 133.06 (ArH) ppm. IR: 3100, 2700 (br) (-); 1583, $1457,744,700$ (ArH) $\mathrm{cm}^{-1}$.

\section{1-(2'-pyridinylmethanamino)-11-methyl-1,4,8,12- tetraazacyclopentadecane,}

$1.5 \mathrm{HCl}(5.0 \mathrm{~g}, 11 \mathrm{mmol})$ was dissolved in $100 \mathrm{~mL}$ water and the $\mathrm{pH}$ adjusted to $\sim 6$ with $2.5 \mathrm{M} \mathrm{NaOH}$. Ethanol $(900 \mathrm{~mL})$ was added and the $\mathrm{pH}$ readjusted to -6. $\mathrm{Na}\left[\mathrm{CN}\left(\mathrm{BH}_{3}\right)\right](2.4 \mathrm{~g}, 38 \mathrm{mmol})$ was added followed by 2-pyridine carboxaldehyde $(1.1 \mathrm{~mL}, 12$ mmol) and the $\mathrm{pH}$ was readjusted to 6 with $1 \mathrm{M} \mathrm{HCl}$. The reaction and workup to the $\mathrm{Cu}$ (II) complex was exactly as for 2 above. The resulting blue solution was diluted and loaded onto a column of SP Sephadex C25 resin and washed with water. Two bands were eluted with $0.25 \mathrm{M} \mathrm{NaClO}_{4}$. The first, major band was reduced in volume to give a purple precipitate $(1.2 \mathrm{~g}$, $18 \%)$; more was recovered on extended standing. As isolated, the pendant pyridine is protonated. Anal. Calc for $\mathrm{C}_{18} \mathrm{H}_{35} \mathrm{Cl}_{3} \mathrm{CuN}_{6} \mathrm{O}_{12} \cdot \mathrm{H}_{2} \mathrm{O} \cdot 1.5 \mathrm{NaClO}_{4}$ : C, 24.05; H, 4.15; N, 9.3. Found: C, 24.15; H, 4.2; N, 9.0 $\%$. Electronic spectrum (water): $\lambda_{\max } 601 \mathrm{~nm}(\varepsilon 164$ $\mathrm{M}^{-1} \mathrm{~cm}^{-1}$ ). IR Spectrum (KBr disc): $3261,3187,1630$ (NH); 2930, 2870 (CH); 1482, 739 (py); 1150, 1068, $631\left(\mathrm{ClO}_{4}^{-}\right) \mathrm{cm}^{-1}$. The free ligand can be isolated as described for the close analogue 2 .

$$
\begin{gathered}
\text { 5-(Hydroxymethyl)-5'-(10"-methyl-1",4",8",12"- } \\
\text { tetraazacyclopentadecane-10"-amino }) \\
-\left(2,2^{\prime}\right. \text {-dipyridine), }
\end{gathered}
$$

5,5'-Bis(bromomethyl)-(2,2'-dipyridine) $(0.35 \mathrm{~g}$, $1.0 \mathrm{mmol})$ [16], 1 (0.5 g, $2.0 \mathrm{mmol})$, triethylamine $(0.27 \mathrm{~mL}, 4.0 \mathrm{mmol})$ and tetrabutylammonium iodide $(0.74 \mathrm{~g}, 0.40 \mathrm{mmol})$ were dissolved in $10 \mathrm{~mL}$ freshly distilled $\mathrm{CH}_{2} \mathrm{Cl}_{2}$, and the mixture stirred for 2 days, after which time the solvent was removed, and the resulting mixture dissolved in water. $\mathrm{CuCl}_{2} \cdot 2 \mathrm{H}_{2} \mathrm{O}$ $(0.35 \mathrm{~g}, 2.0 \mathrm{mmol})$ was added, the solution diluted and loaded onto a column of SP Sephadex C-25 resin.
Three bands were eluted with sodium chloride $(\leq 1$ $M)$. The last band was reloaded onto a SP-Sephadex $\mathrm{C}-25$ cation exchange column and eluted with $1 \mathrm{M}$ $\mathrm{NaClO}_{4}$. The resulting solution was reduced in volume to give a pale purple precipitate, which proved to be the mono-substituted compound, $\mathrm{Cu}(4)^{2+}$. Anal. Calc for $\mathrm{C}_{24} \mathrm{H}_{39} \mathrm{Cl}_{2} \mathrm{CuN}_{7} \mathrm{O}_{9}: \mathrm{C}, 34.7 ; \mathrm{H}, 5.2 ; \mathrm{N}, 11.8$. Found: C, 34.7; H, 5.3; N, $11.7 \%$. Electronic spectrum (water): $\lambda_{\max } 586 \mathrm{~nm}\left(\varepsilon 211 \mathrm{M}^{-1} \mathrm{~cm}^{-1}\right)$. IR Spectrum (KBr disc): 3270, 3209 (NH); 2930, 2875 (CH); 1578, 1438, 760, 667 (bipy); 1088, 1125, 659 $\left(\mathrm{ClO}_{4}^{-}\right) \mathrm{cm}^{-1}$. For NMR spectroscopy, $10 \mathrm{mg}$ of this sample was dissolved in $2 \mathrm{~mL} \mathrm{D}_{2} \mathrm{O}$ and stirred with zinc amalgam under nitrogen until the blue colour disappeared, forming the zinc complex. ${ }^{1} \mathrm{H}$ NMR ( $\mathrm{Zn}$ complex) $\left(\mathrm{D}_{2} \mathrm{O}\right): \delta 1.76\left(\mathrm{~s}, 3 \mathrm{H},-\mathrm{CH}_{3}\right), 2.26(\mathrm{~m}, 4 \mathrm{H}$, C-CH $\left.{ }_{2}-\mathrm{C}-\right), 2.81-3.77\left(\mathrm{~m}, 18 \mathrm{H},-\mathrm{N}-\mathrm{CH}_{2}-\& \mathrm{CH}_{2}-\right.$ $\mathrm{OH}), 4.23\left(\mathrm{~s}, 2 \mathrm{H},-\mathrm{N}-\mathrm{CH}_{2}-\mathrm{Ar}\right), 8.31-8.41(\mathrm{~m}, 6 \mathrm{H}$, ArH) ppm.

The second dark purple band of a higher-charged copper complex off the Sephadex chromatography column is believed to be the dimeric species, 5,5'-

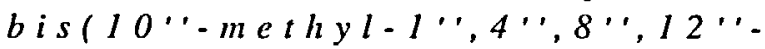
tetraazacyclopentadecane-10"-amino)(2,2'dipyridine). This was reloaded onto a Sephadex cation exchange column and eluted with $1 \mathrm{M} \mathrm{NaClO}$, but due to the very limited amount of this product, a solid was not isolated. Acid stability is consistent with the presence of a macrocyclic complex, and electrochemical properties support the formulation. Electronic spectrum (water): $\lambda_{\max } 577 \mathrm{~nm}$.

$$
\begin{aligned}
& \text { 1,4-Bis(10'-methyl-1;,4;, }, 12^{\prime}- \\
& \text { tetraazacyclopentacecane-10' } \\
& \text {-aminomethyl)benzene, }
\end{aligned}
$$

(1) $5 \mathrm{HCl}(5.9 \mathrm{~g}, 13 \mathrm{mmol})$ was dissolved in 100 $\mathrm{mL}$ water and the $\mathrm{pH}$ adjusted to -6 with $2.5 \mathrm{M}$ $\mathrm{NaOH}$. Ethanol $(900 \mathrm{~mL})$ was added, and the $\mathrm{pH}$ readjusted to $\sim 6$. $\mathrm{Na}\left[\mathrm{CN}\left(\mathrm{BH}_{3}\right)\right](2.4 \mathrm{~g}, 38 \mathrm{mmol})$ was added followed by terephthalaldehyde $(0.7 \mathrm{~g}, 5.2$ mmol) and the $\mathrm{pH}$ was readjusted to 6 with $1 \mathrm{M} \mathrm{HCl}$. The $\mathrm{pH}$ was maintained at $\sim 6$ for 7 hours by the dropwise addition of $1 \mathrm{M} \mathrm{HCl}$ as required, and the mixture was left stirring overnight. The $\mathrm{pH}$ of the 
solution was readjusted to $\sim 12$, the solvent removed and the solid extracted with chloroform. Solvent removal yielded a solid that was dissolved in water, $\mathrm{CuCl}_{2} .2 \mathrm{H}_{2} \mathrm{O}(2.5 \mathrm{~g}, 15 \mathrm{mmol})$ added, and the blue solution diluted and loaded onto a column of SP Sephadex C-25 resin and washed with water. Three major bands were eluted with $0.25 \mathrm{M} \mathrm{NaCl}$. The last of these bands (others proving to be monomers) was reloaded onto a column of SP Sephadex C-25 resin and eluted with $1 \mathrm{M} \mathrm{NaClO}_{4}$. Evaporation of the solvent gave a purple solid. Anal. Calc for $\mathrm{C}_{32} \mathrm{H}_{64} \mathrm{Cl}_{4} \mathrm{Cu}_{2} \mathrm{~N}_{10} \mathrm{O}_{16} \cdot 2 \mathrm{HClO}_{4}-4 \mathrm{H}_{2} \mathrm{O}: \mathrm{C}, 27.7 ; \mathrm{H}, 5.35$; N, 10.15. Found: C, 27.7; H, 5.0; N, $9.7 \%$. UV-vis $\left(\mathrm{H}_{2} \mathrm{O}\right) \mathrm{pH} 3.2: \lambda_{\max } 575 \mathrm{~nm}\left(\varepsilon 170 \mathrm{M}^{-1} \mathrm{~cm}^{-1}\right) ; \mathrm{pH} 6.9:$ $\lambda_{\max } 585 \mathrm{~nm}\left(\varepsilon 245 \mathrm{M}^{-1} \mathrm{~cm}^{-1}\right)$. IR: $3221,3114(\mathrm{CH})$; $3000-2600(-) ; 1608(\mathrm{NH}) ; 1558,1430$ (ArH); $1114,1086,625\left(\mathrm{ClO}_{4}^{-}\right) \mathrm{cm}^{-1}$. The solid was redissolved in water and reduced via $\mathrm{Zn} /$ acid as described for 1 . The resulting solution was filtered and loaded onto a Dowex $50 \mathrm{~W} \times 2\left(\mathrm{H}^{+}\right.$form) cationexchange resin column. Excess zinc ion was removed with $1 \mathrm{M} \mathrm{HCl}$ and the macrocycle eluted with $5 \mathrm{M}$ $\mathrm{HCl}$. The solution was rotary evaporated to dryness and recrystallised from $1 \mathrm{M} \mathrm{HCl} /$ acetone $(0.31 \mathrm{~g}, 3$ \%). Elemental analysis: Calc for $\mathrm{C}_{32} \mathrm{H}_{74} \mathrm{Cl}_{10} \mathrm{~N}_{10} \cdot 10 \mathrm{HCl} 9.5 \mathrm{H}_{2} \mathrm{O}: \mathrm{C}, 34.2 ; \mathrm{H} 7.7 ; \mathrm{N} 12.2$. Found: $\mathrm{C}, 34.2 ; \mathrm{H}, 8.3 ; \mathrm{N}, 12.4 \%$. ${ }^{1} \mathrm{H}$ NMR $\left(\mathrm{D}_{2} \mathrm{O}\right): \delta$ $1.70\left(\mathrm{~s}, 6 \mathrm{H},-\mathrm{CH}_{3}\right), 2.18\left(\mathrm{~m}, 8 \mathrm{H},-\mathrm{C}-\mathrm{CH}_{2}-\mathrm{C}-\right), 3.19-$ $3.67\left(\mathrm{~m}, 32 \mathrm{H},-\mathrm{N}-\mathrm{CH}_{2}-\right), 4.36\left(\mathrm{~s}, 4 \mathrm{H},-\mathrm{N}-\mathrm{CH}_{2}-\mathrm{Ar}\right)$, 7.59 (s, 4H, -ArH) ppm. ${ }^{13} \mathrm{C}\left({ }^{1} \mathrm{H}\right.$-decoupled) NMR $\left(\mathrm{D}_{2} \mathrm{O}\right): \delta 16.22\left(-\mathrm{CH}_{3}\right), 19.38\left(-\mathrm{C}-\mathrm{CH}_{2}-\mathrm{C}-\right), 40.12$, 42.92, 44.72 (-N-CH$-\mathrm{C}-\mathrm{C}-\mathrm{N}), 44.94$ (tert. C), 48.35 (-N-CH $2-\mathrm{C}-\mathrm{N}-$ ), 57.99 (-N-CH$-\mathrm{Ar}), 129.74,129.60$ (ArH) ppm. IR Spectrum (KBr): $3100-2300$ (br) (); $1587,1455(\mathrm{ArH}) \mathrm{cm}^{-1}$.

\section{1,3-Bis (10'-methyl-1;,4;8',12'- tetraazacyclopentacecane-10' -aminomethyl)benzene,}

(1) $5 \mathrm{HCl}(5.9 \mathrm{~g}, 13 \mathrm{mmol})$ was dissolved in 100 $\mathrm{mL}$ water and the $\mathrm{pH}$ adjusted to -6 with $2.5 \mathrm{M}$ $\mathrm{NaOH}$. Ethanol (900 $\mathrm{mL}$ ) was added, and the $\mathrm{pH}$ readjusted to $\sim 6 . \mathrm{Na}\left[\mathrm{CN}\left(\mathrm{BH}_{3}\right)\right](2.4 \mathrm{~g}, 38 \mathrm{mmol})$ was added followed by isophthalaldehyde $(0.7 \mathrm{~g}, 5.2$ mmol) and the $\mathrm{pH}$ was readjusted to 6 with $1 \mathrm{M} \mathrm{HCl}$. Reaction, workup, complexation and chromatography were exactly as described for 5 above. Three major bands were eluted from the SP-Sephadex C-25 column with $0.25 \mathrm{M} \mathrm{NaCl}$. The last of these bands (others proving to be monomeric) was reloaded onto another column of SP Sephadex and eluted with $1 \mathrm{M} \mathrm{NaClO}_{4}$. Evaporation of the solvent gave a purple solid. Anal. Calc for $\mathrm{C}_{32} \mathrm{H}_{64} \mathrm{Cl}_{4} \mathrm{Cu}_{2} \mathrm{~N}_{10} \mathrm{O}_{16}: \mathrm{C}, 37.65 ; \mathrm{H}, 8.0 ; \mathrm{N}$, 13.35. Found: $\mathrm{C}, 37.65 ; \mathrm{H}, 7.7 ; \mathrm{N}, 13.3 \%$. Electronic spectrum (water): $\mathrm{pH} \mathrm{3,} \lambda_{\max } 575 \mathrm{~nm}\left(\varepsilon 280 \mathrm{M}^{-1} \mathrm{~cm}^{-1}\right)$; $\mathrm{pH} 6.4, \lambda_{\max } 584$ ( $\varepsilon$ 341). IR Spectrum (KBr disc): 3218 , $3140,1624(\mathrm{NH}) ; 2938,2876(\mathrm{CH}) ; 1450,1089,763$, $695(\mathrm{ArH}) \mathrm{cm}^{-1}$. The complex was redissolved in water, reduced via $\mathrm{Zn} /$ acid and chromatographed as described for $\mathbf{5}$ above, and the free amine salt recrystallised from 1 M HCl/ethanol $(0.37 \mathrm{~g}, 3 \%)$. Anal. Calc for $\mathrm{C}_{32} \mathrm{H}_{64} \mathrm{~N}_{10} \cdot 10 \mathrm{HCl} 4 \mathrm{H}_{2} \mathrm{O} 0.25 \mathrm{EtOH}$ : C, 37.65; H, 8.1; $\mathrm{N}, 13.5$. Found: $\mathrm{C}, 37.65 ; \mathrm{H}, 8.05 ; \mathrm{N}, 13.4 \% .{ }^{1} \mathrm{H}$ NMR $\left(\mathrm{D}_{2} \mathrm{O}\right): \delta 1.87\left(\mathrm{~s}, 6 \mathrm{H},-\mathrm{CH}_{3}\right), 2.37,(\mathrm{~m}, 8 \mathrm{H},-\mathrm{C}-$ $\mathrm{CH}_{2}$-C-), $3.38-3.80,\left(\mathrm{~m}, 32 \mathrm{H},-\mathrm{N}-\mathrm{CH}_{2}-\right), 4.57$ (s, $4 \mathrm{H}$, -N-CH $2-A r), 7.78-7.90(\mathrm{~m}, 4 \mathrm{H}, \mathrm{ArH}) \mathrm{ppm} .{ }^{13} \mathrm{C}$ ( ${ }^{1} \mathrm{H}-$ decoupled) NMR $\left(\mathrm{D}_{2} \mathrm{O}\right): \delta 15.89\left(-\mathrm{CH}_{3}\right), 18.62(-\mathrm{C}-$ $\mathrm{CH}_{2}$-C-), 40.00, 42.52, 44.35 (N-CH${ }_{2}$-C-C-N-), 44.58 (tertiary C), $47.77\left(-\mathrm{N}-\mathrm{CH}_{2}-\mathrm{C}-\mathrm{N}-\right), 57.58\left(-\mathrm{N}-\mathrm{CH}_{2}-\right.$ Ar), $127.99,130.10,130.20(\mathrm{ArH})$ ppm. IR: $3100-$ 2600 (br) (-); 1593, 1452, 746, 695 (ArH) $\mathrm{cm}^{-1}$.

Other Complexes. The pyridine-containing macrocycle 3,7,11,17-tetraazabicyclo[1 1.3.1] heptadeca-1(17),13,15-triene (7) and its analogues (8 - 13) and their complexes have been described previously [17-21]. Cyclam (14) and its $\mathrm{N}$-substituted derivatives $N, N^{\prime}, N^{\prime \prime}, N^{\prime \prime}$-tetrakis(methylbenzyl)1,4,8,11-tetraazacyclotetradecane (15) and $N, N^{\prime}, N^{\prime \prime}, N^{\prime \prime}$-tetrakis(methylpyridine)-1,4,8,11tetraazacyclotetradecane (16) have been reported previously [22-24]. The triamines cyclohexane-1,3,5triamine (17), 1,4,7-triaazacyclononane (18), $N, N^{\prime}, N^{\prime \prime}$-trimethyl-1,4,7-triaazacyclononane (19) and 2,5,8-triazabicyclo[7.4.0 1.9 tridecane (20) have also been reported previously [25-28], as have the dinucleating macrocycle 3,13-dimethyl-3,13-dinitro1,5,11,15-tetraazacycloeicosane-8,18-diol (21) and its dithiol analogue $(22)[29,30]$. The C-dipendant macrocycle trans-6,13-dimethyl-1,4,8,11- 
tertaazacyclotetradecane-6,13-diamine (23), prepared via the same route as the latter two compounds [31], is also well known. Authentic analytically pure samples of ligands and or their complexes were available for examination, with the latter prepared if required as complexes in situ by mixing a warmed solution of $\mathrm{Cu}(\mathrm{II})$ ion (nitrate salt) and ligand solutions in appropriate molar ratios in water or methanol.

\section{DNA Production and Isolation}

DNA hydrolytic cleavage experiments employed plasmid DNA (2961 bp) that was prepared and isolated according to both standard protocols and quicker column 'midipreps' (using Nucleobond AX 2000 and AX 5000 kits). In the Standard Protocol [32], the bacterial strain JM109 Escherichia coli was transformed with pBluescript II KS $(+/-)$ plasmid DNA via heat shock, and transformed bacteria were then grown on agar containing ampicillin for 12 hours at $37^{\circ} \mathrm{C}$. All bacteria grown that have successfully taken up the foreign plasmid (pBluescript II KS (+/-)), which contains an ampicillin resistant gene, become ampicillin resistant whereas undesired bacteria are killed. One colony from the agar plate was removed and further incubated in bacterial growth medium containing ampicillin for 12 hours, and this bacteria culture employed for the plasmid DNA isolation. An aliquot $(1.5 \mathrm{~mL})$ of the incubation mixture was transferred to a new sterile Eppindorf tube and centrifuged for $20 \mathrm{sec}$ at $14000 \mathrm{rpm}$. The pellet was treated with successive additions of glucose/tris/EDTA solution mixture $(100 \mu \mathrm{L})$, alkaline SDS $(200 \mu \mathrm{L})$, potassium acetate in acetic acid $(150 \mu \mathrm{L})$, and finally 'zip' solution $(24: 1: 1$ chloroform:iso-propanol:phenol; $450 \mu \mathrm{L}$ ), with gentle mixing between additions. The aqueous phase was treated with $900 \mu \mathrm{L}$ of $100 \%$ ethanol and centrifuged for $15 \mathrm{~min}$ at $14000 \mathrm{rpm}$. The transparent pellet of plasmid DNA obtained was re-suspended in $40 \mu \mathrm{L}$ of water. This preparation was completed several times, with DNA samples combined and concentrated. The purity of the plasmid was probed by mini-gel electrophoresis and also by determining the ratio of absorbance at $260 \mathrm{~nm}\left(\lambda_{\max }\right.$ for nucleic acid) and 280 $\mathrm{nm}\left(\lambda_{\max }\right.$ for protein) in the UV spectrum. The concentration of the purified plasmid was determined by the absorbance at $260 \mathrm{~nm}\left(1.0 \mathrm{OD}_{260}=50 \mu \mathrm{g} / \mathrm{mL}\right)$. The gel electrophoresis of the isolated plasmid showed an undetermined amount of RNA impurity and also verified that the correct plasmid was harvested (pBluescript II KS, 2961 bp), by indicating that the size of the plasmid was in the anticipated range 2027-3530 bp. The RNA impurity was removed by treating the whole plasmid solution with DNase-free RNase for one hour at room temperature. Final nucleic acid batches typically had a concentration of $6.7 \mathrm{mg} / \mathrm{mL}(400 \mu \mathrm{L})$ with good purity $(260: 280 \mathrm{~nm}$ ratio $=1.845)$. The plasmid was stored at $-20^{\circ} \mathrm{C}$ until needed.

In the quicker Column Protocol [33], the bacterial strain JM109 Eschericha coli was also used and transformed with pBluescript II KS (-) plasmid DNA via heat shock, grown on agar containing ampicillin and the DNA harvested and purified using the Nucleobond AX 5000 kit, with purity again checked by minigel electrophoresis and UV spectroscopy.

\section{Cleavage Assays and Gel Electrophoresis}

Cleavage Assays - The cleavage assays were usually completed in triplicate for both metal complexes and experimental controls. The experiment was typically initiated by the combination of $20 \mu \mathrm{L}$ of a $0.15 \mathrm{M}$ HEPES buffer, $20 \mu \mathrm{L}$ of a $1.9 \times 10^{-3} \mathrm{M}$ metal complex solution (sterile, filtered) and $10 \mu \mathrm{L}$ of a 0.6 $\mathrm{mg} / \mathrm{mL}$ plasmid DNA solution. Water replaced the metal complex solutions in the negative control. The assays were maintained at $37^{\circ} \mathrm{C}$ at $\mathrm{pH} 7.6$ for designated time periods (typically $6-12 \mathrm{hrs}$ ), before the reactions were halted by precipitation of the DNA upon the addition of two volumes of absolute ethanol and 0.1 volumes of $3 \mathrm{M}$ sodium acetate. The samples were stirred, allowed to stand at room temperature for $15 \mathrm{~min}$, then centrifuged at $14000 \mathrm{rpm}$ for $15 \mathrm{~min}$. The supernatant was carefully removed and the DNA pellets were resuspended in distilled water $(10 \mu \mathrm{L})$ and prepared for analysis by gel electrophoresis [32]. For time dependence studies, reaction of a set of equivalent samples was quenched at different times and samples worked up to the DNA pellet dissolved in 
water stage as above. These solutions were then stored at $4^{\circ} \mathrm{C}$ until all samples were ready for gel electrophoresis. For any prolonged storage (more than $48 \mathrm{~h}$ ), the samples were kept at $-20^{\circ} \mathrm{C}$, with appropriate controls.

Gel Electrophoresis - The amount of degradation of DNA caused by the respective complexes was determined by gel electrophoresis. A single multi-well electrophoresis gel was used. Samples were usually run in triplicate along with a molecular marker and a series of controls. The three forms of plasmid DNA can be separated on the gel and visualised by staining with ethidium bromide. To each of the prepared samples, $2.5 \mu \mathrm{L}$ of gel loading solution (bromophenol blue) was added and a marker sample was made comprising $7 \mu \mathrm{L}$ of water, $2 \mu \mathrm{L}$ of gel loading solution and $1 \mu \mathrm{L}$ of a DNA molecular marker (Lambda EcoRI HindIII digest, Sigma-Aldrich). The electrophoresis was carried out at $80-130 \mathrm{~V}$ in a TRIS-borate ( $1 \times \mathrm{TBE}$ ) running buffer solution using a gel comprising $0.8 \%$ agarose in $1 \times \mathrm{TBE}$ stained with ethidium bromide ( $2 \mu \mathrm{L}$ of $10 \mathrm{mg} / \mathrm{mL}$ in the gel mixture). Gels were stopped after the dye from the gel loading buffer had migrated at least $75 \%$ of the total length of the gel. The results were then recorded on camera and also usually digitised for computer analysis using a BioRad Fluor-S multi-imager and analysed with BioRad Discovery One software. Once the gel image had been charted, the array of data produced by the software that describes the intensity versus the $R_{f}$ values of each lane was imported into Excel. The data for each sample (usually in triplicate) was averaged, and peak heights for each plasmid form were determined. Peak height was used as the measure of the amount of DNA at the respective $R_{f}$ (supercoiled, linear and circular) location in each sample lane. An active compound is indicated by the increased amount of usually the linear (form III) DNA relative to the initial form (form I) in a lane, and the activity was measured as $\%$ cleavage. The negative control indicates the amount of spontaneous degradation or pre-existing degraded plasmid forms and can therefore be used to correct \% cleavage values to define activity of the metal complex alone.

\section{Physical Methods}

Spectroscopy - NMR spectra were recorded on a Brunker Avance DPX-300 spectrometer in $\mathrm{D}_{2} \mathrm{O}$ or $\mathrm{CDCl}_{3}$, using tetramethylsilane or trimethylsilylpropionate as the internal reference. IR spectra were recorded on a Bio-Rad FTS-7 or PerkinElmer Paragon 1000 Fourier transform spectrometer, using $\mathrm{KBr}$ dises or between $\mathrm{NaCl}$ plates in dichloromethane. Electronic spectra were recorded in aqueous solutions using a Hitachi $220 \mathrm{~A}$ spectrophotometer. EPR spectra were measured on frozen glasses with a Bruker ElexSys E500 spectrometer at $77 \mathrm{~K}$.

Cyclic Voltammetry - CV employed a VMP singleboard-computer controlled multi-potentiostat system as analyser and a three-electrode system involving a $\mathrm{Ag} / \mathrm{AgCl}$ references electrode, platinum wire auxiliary electrode and glassy carbon or gold disc working electrode. Solutions, $0.1 \mathrm{M}$ in $\mathrm{NaClO}_{4}$ and $-1.0 \times 10^{-3} \mathrm{M}$ in complex, were purged with nitrogen gas prior to measurement. EC-Lab software was used for data acquisition.

Potentiometric titrations - These were performed using a Metrohm 665 Dosimat burette controlled by a Dell PC using Matlab-based software. Experiments were carried out at $25^{\circ} \mathrm{C}$ in aqueous solution at constant ionic strength $\left(0.5 \mathrm{M} \mathrm{NaClO}_{4}\right.$ or $\left.\mathrm{NaNO}_{3}\right)$ under nitrogen. The sodium hydroxide solution was prepared from $\mathrm{NaOH}$ pellets in freshly boiled water and stored under nitrogen. The solution was standardised by titration with $0.01 \mathrm{M}$ potassium hydrogen phthalate. Free ligand and complex data were analysed and fitted simultaneously using a program (Globpot) developed in our laboratories at the University of Newcastle. All titrations were repeated at least twice. For ligands, solution of $0.1 \mathrm{M}$ $\mathrm{NaOH}$ was added stepwise to a solution containing $\sim 5$ $\times 10^{-3} \mathrm{M}$ ligand as well as an acid excess $\left(\mathrm{HClO}_{4}\right.$ or $\mathrm{HNO}_{3}$ ) of between 10 and $100 \%$. The volume of ligand solution was between 3 and $20 \mathrm{~mL}$, depending on the availability of the ligand. The increment size and total volume of $\mathrm{NaOH}$ solution added was adjusted accordingly, to give a final $\mathrm{pH} \sim 12$. For complexes, samples were prepared in situ from $\sim 5 \times$ $10^{-3} \mathrm{M}$ ligand solution by the addition of $\sim 0.9(-1.8$ 
for dimers) equivalents of $\mathrm{Cu}\left(\mathrm{ClO}_{4}\right)_{2}$. The solution was adjusted to $\mathrm{pH} \sim 7$ and left to equilibrate for up to $1 \mathrm{hr}$. Before titration, acid was added to give an acid excess of $\sim 20 \%$. The solution was then titrated with $0.1 \mathrm{M} \mathrm{NaOH}$ in the same manner as the free ligand.

Molecular Modelling - Modelling employed the $\mathrm{MM}+$ (Hyperchem Versions 6 and 7) [34] or Amber (MOMEC97) [35] forcefields, implemented in the appropriate software packages.

\section{RESULTS AND DISCUSSION}

\section{Syntheses and Characterisation}

Metal-directed Mannich type reactions offer facile routes to C-pendant polyaza macrocycles, and have been closely studied in recent decades [36-38]. This chemistry provides routes to the amine-pendant macrocycles such as $\mathbf{2 3}$, where the amine pendants are available for additional chemistry leading to pendant elaboration or linking reactions. The macrocycle 1 , which carries a single pendant group, has been elaborated here by both extending the pendant amine group through attachment of benzyl (to form 2) and methylpyridyl groups (3). The new ligands were prepared by the previously described method of reductive amination of an aldehyde with the macrocycle through the use of cyanoborohydride [39, 40]. This method, which requires only mild conditions [41], was straightforward, although it proved most facile for the product to be separated from the reaction mixture by chromatography of the $\mathrm{Cu}$ (II) complex. A number of different routes to the extension of a primary amine are apparent. Carbodiimide coupling to a carboxylic acid was initially investigated, as this method typically employs mild reaction conditions. No reaction was observed, however, using either 1,3-dicyclohexylcarbodiimide and 1-hydroxybenzotriazole or 1-(3dimethylaminopropyl)-3-ethylcarbodiimide hydrochloride (EDC). Furthermore, titanium tetrachloride was used in an attempt to promote amide formation from 1, with no observable reaction. Carbodiimide coupling agents have been used previously to prepare an amide from an amine pendant macrocycle; the aniline substituted macrocycle 24 was coupled to both CM Bio-Gel A and horse heart cytochrome $C$ using EDC [42]. It is possible that, in the case of 1 , the close proximity of the macrocycle framework to the primary amine causes a high degree of electronic and steric hindrance at the primary amine, inhibiting any reaction under the mild conditions of carbodiimide coupling. The primary amine reacted in the case of the aniline substituted compound is much further removed from the macrocycle, thus significantly reducing the likelihood of steric hindrance from this aspect. Further, in the latter case, one is dealing with an aromatic primary amine and in the former case with a primary amine attached to an aliphatic tertiary carbon, so electronic as well as steric differences can be anticipated.

The reductive amination reaction is thought to occur via two steps, involving imine formation followed by reduction of this intermediate to the amine [43]. The first step is an equilibrium reaction, favouring the reactants. The back reaction, however, is slow, and the fast reduction of the iminium intermediate allows the final product to be trapped. Fortunately, the optimal $\mathrm{pH}$ for both reactions is -6 . This is also important in the reaction with 1 , as the $\mathrm{pK}_{\mathrm{a}}$ value of the pendant amine is 6.1. Thus, under more acidic conditions, the amine would be protonated and formation of the iminium intermediate would be strongly impaired or would not occur. This method was utilised to successfully to prepare 2 and 3 , albeit in low to moderate yields, via reaction of 1 with the appropriate aldehyde, and would seem generally applicable. Two dimeric compounds were subsequently also synthesised by linking two 1 macrocycles together via their pendant amines through bridging ortho- or para-xylene linkages (forming 5 and 6 respectively) from the appropriate dialdehydes using reductive alkylation via cyanoborohydride.

A related compound with a substituted bipyridyl group, 4, was synthesised via an alternative route by reaction of 1 with a brominated substituted dipyridine moiety, 5,5'-bis(bromomethyl)-(2,2'-dipyridine). Although there are no previous reports of amine- 
pendant macrocycles being substituted in this way, this method is an established and powerful method for substitution of an amine [44-46]. Although dimerisation can occur in this reaction, and a minor amount of this forms, a monosubstituted species with one bromo group replaced by an alcohol group via undesired competing hydrolysis was the major product isolated and characterised.

Spectroscopic results (see Experimental) are fully consistent with the structures assigned. The copper(II) complexes of 2 and 3 are structurally closely related to the compound 24 previously prepared [42], and spectroscopic properties are very similar. In frozen solution, $\mathrm{Cu}(2)^{2+}$ exhibits an ESR spectrum with $\mathrm{g}_{1}$ $2.047, g_{\|} 2.215$ and $A_{\perp} 22 \mathrm{G}, A_{\|} 203 \mathrm{G}$, comparable to a range of tetraaza-macrocyclic $\mathrm{Cu}$ (II) complexes that display square planar or Jahn-Teller elongated octahedral geometry in solution [47]. The ESR spectra of the dimers $\mathrm{Cu}_{2}(5)^{4+}$ and $\mathrm{Cu}_{2}(6)^{4+}$ are very similar but differ slightly from that of the monomer. However, they do not display the complex coupling pattern found where the two copper centres are confined by ligand geometry to be close together [48], supporting the view that the reasonably flexible linker permits the copper centres to orientate themselves distant from each other in solution sufficient to be uncoupled (vanishingly small exchange coupling and dipolar coupling), further supported by the absence of a detectable half-field signal due to $\Delta \mathrm{Ms}= \pm 2$ transitions. Unfortunately, we have been unable to determine a crystal structure to probe the solid state arrangement; however, related compounds tend to show the metal centres well separated in the solid state also [49].

\section{Cyclic voltammetry}

Characterisation of new complexes was extended employing cyclic voltammetry. The electrochemistry of copper(II) amine complexes is dominated by the $\mathrm{Cu}(\mathrm{II}) / \mathrm{Cu}(\mathrm{I})$ couple that occurs typically between -0.5 and $-1.0 \mathrm{~V}$ [50]. Although subsequent reduction of $\mathrm{Cu}(\mathrm{I})$ can occur, this is not usually seen before the practical limits of the system; likewise, the $\mathrm{Cu}(\mathrm{II}) / \mathrm{Cu}(\mathrm{III})$ couple is usually not readily accessible. Acyclic tetraamines typically exhibit an electrochemically quasireversible couple [50], since ligand flexibility can support the change from square planar (or octahedral) geometry of $\mathrm{Cu}$ (II) to tetrahedral geometry of $\mathrm{Cu}(\mathrm{I})$. Chemical reversibility of this couple depends on the characteristics of the ligand and solvent system, as $\mathrm{Cu}(\mathrm{I})$ is a labile oxidation state. When an acyclic tetraamine is replaced by a macrocyclic tetraamine, the greater rigidity of the ligand can lead to irreversible behaviour, particularly where the macrocycle is not sufficiently large or flexible to accommodate the lower oxidation state metal ion [51]. Tetrahedral distortion of square planar tetraamine macrocycles is known to increase with ring size $[52,53]$, which suggests that larger rings may lead to enhanced stability in the lower oxidation state. Cyclic voltammetry offers the most convenient method for rapidly probing the redox behaviour of metal complexes, and gauging their electrochemical and tied chemical processes.

Of the saturated tetraaza macrocycles, the $E_{1 / 2}$ for $\mathrm{Cu}(\mathrm{II}) / \mathrm{Cu}(\mathrm{I})$ varies with ring size, as does the reversibility [54]. Small rings, such as 12 -membered cyclen, where the metal ion cannot be accommodated readily within the plane of the $\mathrm{N}$-donors, exhibit, as a result of this structural feature, greater reversibility than the 14-membered cyclam ligand (14), where the metal lies essentially in the plane of the four $\mathrm{N}$ donors. The cyclam complex displays limited reversibility for its $\mathrm{Cu}(\mathrm{II}) / \mathrm{Cu}(\mathrm{I})$ couple, but reversibility rises somewhat as the ring size increases. Both the $E_{1 / 2}$ and reversibility are influenced by the introduction of substituent groups on either the $\mathrm{N}$ donors or the $\mathrm{C}$-framework. Introduction of a $\mathrm{C}$ pendant primary amine group can influence the behaviour through both electronic effects and the ability to bind weakly in axial sites [54]. With 1 , a poorly reversible couple is observed in water (GCE; $100 \mathrm{mV} / \mathrm{s} \mathrm{scan}$ rate $)$ at $\mathrm{E}_{1 / 2}=-0.833 \mathrm{~V}(\Delta \mathrm{E} 165 \mathrm{mV})$ (Figure 1(a)). An additional small anodic wave at $0.350 \mathrm{~V}$ can be assigned to partial rapid dissociation of the $\mathrm{Cu}(\mathrm{I})$ complex to form a species with a different mixed N,O donor set that is reoxidised irreversibly as a result of following rapid recomplexation to reform the tetraamine complex. 
Binding of the pendant amine in the intermediate seems to be involved, given the different behaviour of the unsubstituted $\mathbf{2 5}$.

Introduction of a benzyl group on the pendant amine (forming 2 ) leads to a complex that exhibits classical quasiversible behaviour in water $\left(E_{1 / 2}=\right.$ $0.744 \mathrm{~V}, \triangle \mathrm{E} 110 \mathrm{mV}$; GCE, $100 \mathrm{mV} / \mathrm{s}$ scan rate) (Figure 1(b)) and also in acetonitrile. Not only is the couple shifted as a result of electronic effects of the benzyl pendant, but also the pendant plays a role in both limiting solvent approach to the metal ion
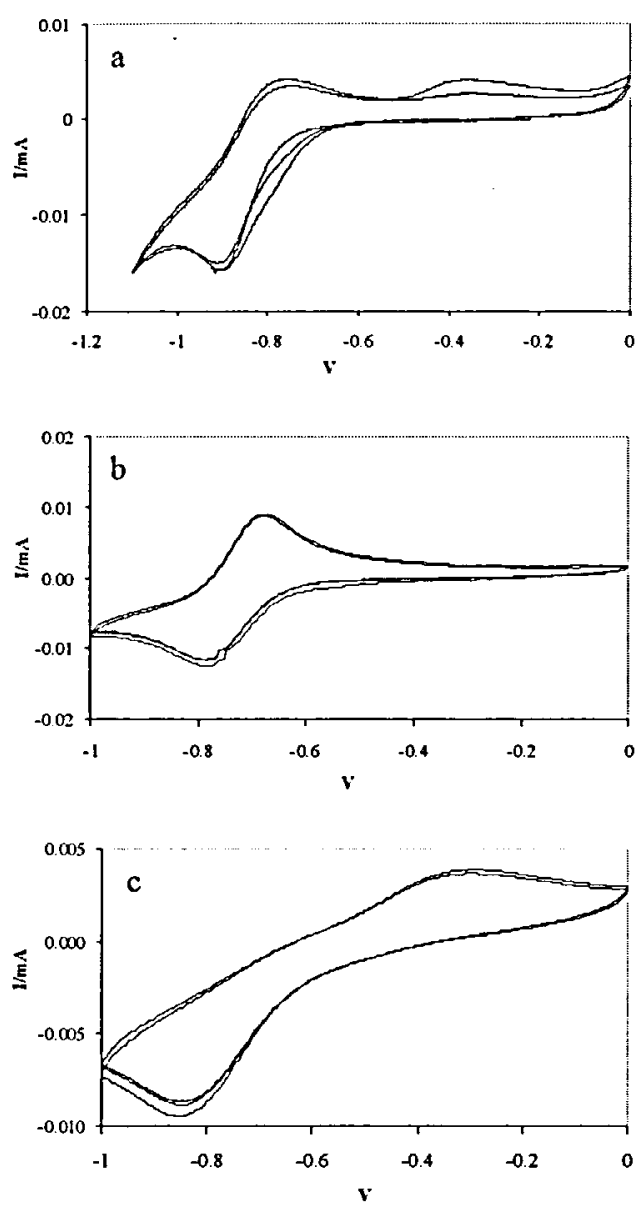

FIGURE 1

Cyclic voltammograms (at a glassy carbon electrode) in water for (a) $\mathrm{Cu}(1)^{2+},(\mathrm{b}) \mathrm{Cu}(2)^{2+}$ and (c) $\mathrm{Cu}(3)^{2+}$. through its hydrophobic character and altering the tendency of the pendant amine to bind because of steric and electronic effects. When the benzene group is replaced by a pyridine (forming 3 ), which offers additional binding options through its heterocyclic nitrogen donor, and lowers hydrophobicity through the presence of the same atom, reversibility of the couple is impaired only slightly $\left(E_{1 / 2}=-0.671 \mathrm{~V}, \Delta \mathrm{E}\right.$ $130 \mathrm{mV}$ ), which may imply that the two pendant donors do not compete for the $\mathrm{Cu}(\mathrm{I})$ strongly. However, a minor second oxidation wave is seen at $0.3 \mathrm{~V}$, possibly associated with a species where the potentially chelating pendant arm of 3 participates. The observation that this minor wave is enhanced at slower scan rates implies a kinetic process governs its appearance, supporting some dissociation of the reduced $\mathrm{Cu}$ centre in a process whose dissociation rate is such that the concentration of dissociated species is moderated by the scan rate.

Attachment of a $2,2^{\prime}$-bipyridyl functionality to the pendant (forming 4) leads to a significant shift in voltammetric behaviour from that with the pendant pyridine (Figure 1(c)). Reversibility is effectively lost, with $\mathrm{E}_{\mathrm{pc}}=-0.820 \mathrm{~V}$ and $\mathrm{E}_{\mathrm{pa}}=-0.346 \mathrm{~V}$. It is believed that this may arise as a result of rapid dissociation of $\mathrm{Cu}$ (I) out of the macrocycle cavity to bind dominantly to the pendant bipy chelate, as this oxidation state has a preference for aromatic over saturated $\mathrm{N}$-donor chelates (Scheme 1). Upon oxidation, rapid recomplexation within the cavity occurs due to a preference of $\mathrm{Cu}$ (II) for the saturated amine groups, regenerating the original macrocyclic complex. In an attempt to intercept this proposed chemistry by complexing the bipy separately, $\mathrm{Fe}(\mathrm{II})$ was added to the solution progressively until a $1: 1$ ratio was reached. The original $\mathrm{E}_{\mathrm{pa}}$ wave at $-0.346 \mathrm{~V}$ diminishes as $\mathrm{Fe}$ (II) concentration is increased to the point where it is no longer seen, which may imply blocking of the bipy site by $\mathrm{Fe}(\mathrm{II})$, preventing the chemistry proposed in Scheme 1. The electrochemical behaviour is complicated by waves associated with the iron, but a poorly defined cathodic wave near $0.84 \mathrm{~V}$ assignable to the $\mathrm{Cu}(\mathrm{II}) / \mathrm{Cu}(\mathrm{I})$ reduction persists, and a poorly defined new wave near $-0.61 \mathrm{~V}$ may represent the reoxidation of the $\mathrm{Cu}(\mathrm{I})$ in this case. 
At least, distinctive behaviour associated with variation of pendant groups is observed, implying a clear role for these groups in the associated chemistry.

[NOTE: insert Scheme I about here]

The dicopper(II) complexes formed with ligands 5 and 6, composed of two 1 ligands linked via meta or para xylyl groups, present an extension of the monomer system represented by 2 , the benzylamine pendant of 1 . The change in voltammetric behaviour is significant. The single quasireversible wave scen for $\mathrm{Cu}(2)^{2+}$ is replaced in the dimers by a complex irreversible pattem featuring two reduction processes and a single oxidation process at a significantly different potential. This is illustrated in Figure 2(a) for dimer $\mathbf{5}$ complexes in acetonitrile. Intuitively, it was thought that the two $\mathrm{Cu}$ (II) centres are sufficiently separate to exhibit a common redox potential. However, this is not the case. Two one-electron steps (from wave-height comparison) occur at $\mathrm{E}_{\mathrm{pc}}=-0.508$ $\mathrm{V}$ and $E_{\mathrm{pc}}=-0.734 \mathrm{~V}$. It is presumed from the absence of significant reversible waves near the same potential that rapid dissociation is involved, promoted in acetonitrile solvent by high stability of $\mathrm{Cu}(\mathrm{I})$ acetonitrile complexes, leading eventually to the two $\mathrm{Cu}(\mathrm{I})$ centres in equivalent donor environments that differ substantially from that of the precursor, which subsequently display common oxidation to $\mathrm{Cu}$ (II) and rapid recomplexation to reform the macrocyclic dimer complex. If one $\mathrm{Cu}$ (II) centre is reduced and dissociates rapidly, the original 'pendant' to the other centre will have changed, so
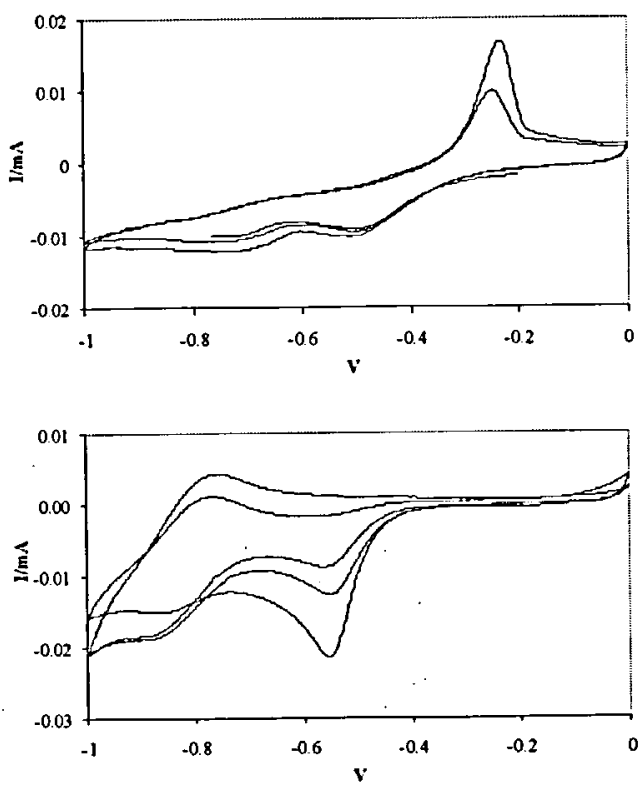

FIGURE 2

Cyclic voltammogram of the dinuclear complexes: $\mathrm{Cu}_{2}(5)^{4+}$ in acetonitrile (top) at a gold working electrode; $\mathrm{Cu}_{2}(6)^{4+}$ in water (bottom) at a glassy carbon working electrode.

that electronic, steric and hydrogen bonding effects will differ and thus alter the reduction potential of the second centre. This centre is then reduced separately, seen as a following wave. Irreversible oxidation at $\mathrm{E}_{\mathrm{pa}}=-0.226 \mathrm{~V}$ is associated with rapid

\section{SCIEME 1}

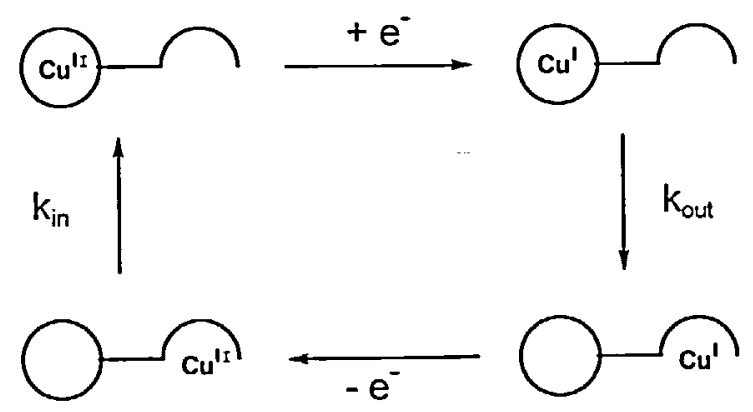


recomplexation kinetics. A role for the solvent is implied, since behaviour in aqueous solution, though still complex, differs. This is illustrated in Figure 2(b) for meta-dibenzam, where two steps still occur $\left(\mathrm{E}_{\mathrm{pc}}\right.$ at $-0.566 \mathrm{~V}$ and $-0.896 \mathrm{~V}$ ), but one displays some reversible behaviour $\left(\mathrm{E}_{\mathrm{pa}}\right.$ at $\left.-0.758 \mathrm{~V}, \Delta \mathrm{E} 138 \mathrm{mV}\right)$. Possibly, poorer solvation of the $\mathrm{Cu}(\mathrm{I})$ in water promotes slower dissociation and retention of partial binding to the macrocycle. Differences in behaviour are also observed changing from a glassy carbon working electrode to a gold working electrode, assignable to the slower heterogeneous electron transfer kinetics for metal complexes associated with gold surfaces. However, these are not substantial and can be accommodated by the mechanistic proposals developed above.

The two-step reduction processes seen for the isomers 5 and $\mathbf{6}$ is also observed for the dimacrocyclic analogue of 4 , where a 2,2'bipyridyl entity replaces the benzene ring of 5 and 6 . This offers the opportunity for involvement of this chelate unit in complexation of the $\mathrm{Cu}(\mathrm{I})$ ions, and a significant shift in $E_{p a}$ to near $0 \mathrm{~V}$ supports this concept. Nevertheless, the mechanistic concepts need not be amended significantly. Overall, the dimers are distinctive in their electrochemistry and differ substantially from the monomer analogue, supporting their characterisation.

\section{Potentiometric titrations}

The acid dissociation constants of free and complexed ligands were determined by potentiometric titrations (Table I). The unsubstituted 15 -membered macrocycle (25) has also been investigated for comparative purposes. The model used to fit the titration curves of 1 and $\mathrm{Cu}(1)^{2+}$ involved protonation of the free ligand up to and a single protonation of the $\mathrm{Cu}$ (II) complex associated with the pendant amine respectively. $\mathrm{The}_{\mathrm{pK}}$ of the fifth protonation of the free ligand is too low to be observed under the experimental conditions. As the stability constant of copper-polyamine macrocycles of
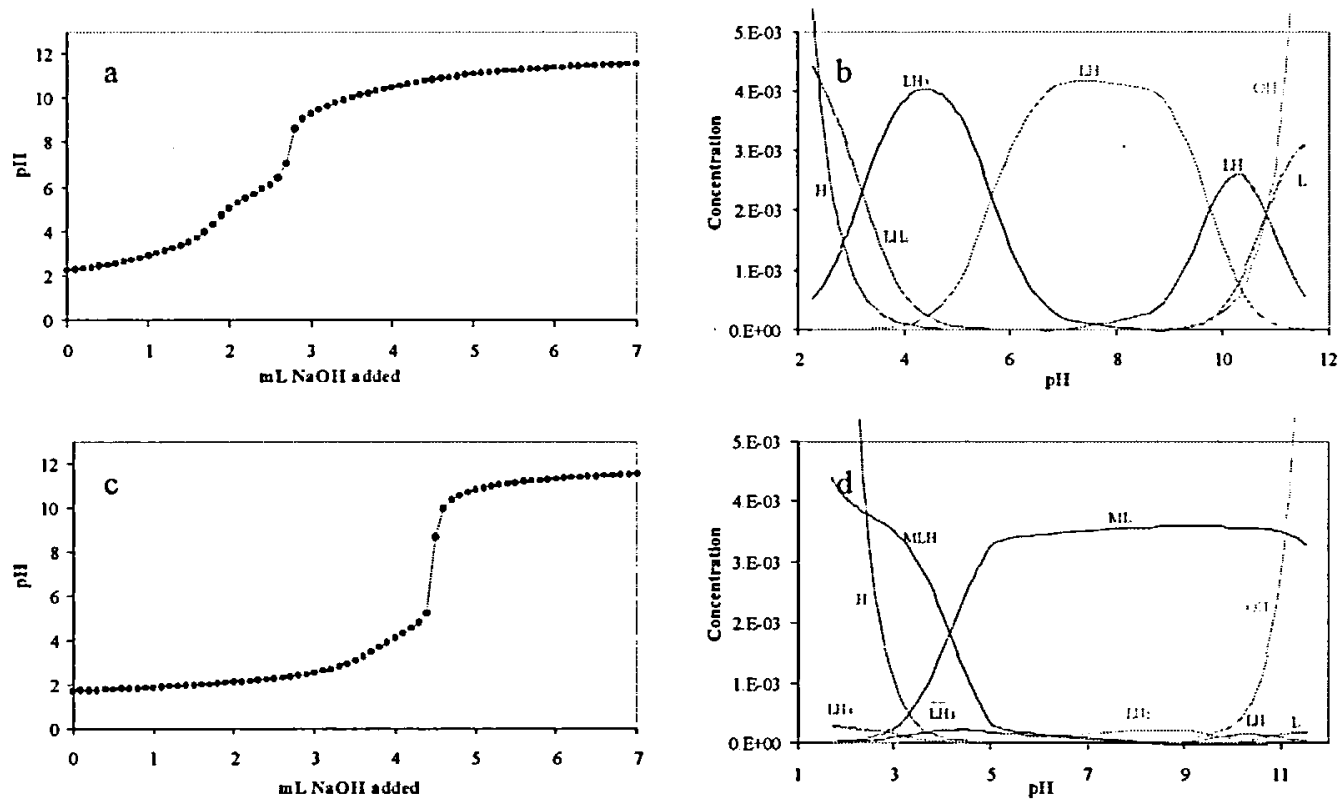

FIGURE 3

Titration curves (dotted) overlaid with calculated fit (solid line) (left) for the titration of 1 (a) and $\mathrm{Cu}(\mathbf{1})$ (c) and species distribution curves (right) for the titration of 1 (b) and $\mathrm{Cu}(1)(d)$. 
TABLE I

Determined $\mathrm{pK}_{\mathrm{a}}$ values (with known literature values in italics and parentheses) for monomer and dimer macrocyclic polyamines.

\begin{tabular}{|c|c|c|c|c|c|c|}
\hline monomers & $1^{\mathrm{a}}$ & $\mathbf{1}^{\mathrm{a}}$ & $\mathbf{2}$ & dimers $^{\mathrm{b}}$ & $\mathbf{5}$ & $\mathbf{6}$ \\
\hline $\mathrm{pK}_{1}$ & $\begin{array}{c}11.13( \pm 0.04) \\
\{1.08,11.23\}\end{array}$ & $\begin{array}{c}10.81( \pm 0.3) \\
\{11.0\}\end{array}$ & not obsd. & $\mathrm{pK}_{2}$ & $11.48( \pm 0.06)$ & $11.54( \pm 0.08)$ \\
\hline $\mathrm{pK}_{2}$ & $\begin{array}{c}9.97( \pm 0.08) \\
\{10.38,10.28\}\end{array}$ & $\begin{array}{c}9.75( \pm 0.3) \\
\{9.5\}\end{array}$ & $9.57( \pm 0.03)$ & $\mathrm{pK}_{3}$ & $10.58( \pm 0.06)$ & $10.48( \pm 0.09)$ \\
\hline $\mathrm{pK}_{3}$ & $\begin{array}{c}5.05( \pm 0.09) \\
\{5.28,5.32\}\end{array}$ & $\begin{array}{c}5.67( \pm 0.4) \\
\{6.1\}\end{array}$ & $4.66( \pm 0.05)$ & $\mathrm{pK}_{4}$ & $9.65( \pm 0.09)$ & $9.55( \pm 0.10)$ \\
\hline $\mathrm{pK}_{4}$ & $3.52( \pm 0.09)$ & $3.20( \pm 0.7)$ & $3.63( \pm 0.06)$ & $\mathrm{pK}_{5}$ & $5.02( \pm 0.07)$ & $5.01( \pm 0.10)$ \\
& $\{3.60,3.79\}$ & $\{3.6\}$ & & & & \\
\hline $\mathrm{pK}_{5}$ & absent & $<2$ & not obsd. & $\mathrm{pK}_{6}$ & $3.90( \pm 0.07)$ & $3.80( \pm 0.09)$ \\
& & $\{<2\}$ & & & & \\
\hline $\mathrm{pK}_{\mathrm{ML}}$ & absent & $4.13( \pm 0.4)$ & $7.05( \pm 0.02)$ & $\mathrm{pK}_{\mathrm{ML}}{ }^{\prime}$ & $4.15( \pm 0.04)$ & $3.93( \pm 0.03)$ \\
\hline
\end{tabular}

(a) literature values in parentheses.

(b) $\mathrm{pK}_{1}$ and $\mathrm{pK}_{8}-\mathrm{pK}_{10}$ are not observed; a second protonation of the dicopper(II) complex $\left(\mathrm{pK}_{\mathrm{ML}}{ }^{2}\right)$ is also not observed.

this type is very high ( $\log \mathrm{K} \geq 20$ are usual) $[55,56]$ and the complexes are kinetically acid and base stable, the complex is not expected to dissociate to any significant degree, so the stability constant is not incorporated in this model. The titration curve, overlayed with the calculated fit, can be seen for both the free ligand and the $\mathrm{Cu}$ (II) complex, as can the species distribution curves throughout the titration (Figure 3). The calculated values are in reasonable agreement with reported values (Table 1 ).

The model used to fit the titration curve of 2 involved three protonations of the free ligand and one protonation of its $\mathrm{Cu}$ (II) complex. As 2 has five possible sites of protonation, there are clearly two protonations that are not observed under the conditions used. As it is probable that the protonation constants are similar to that of 1 , comparison of the two systems suggests that the protonations of $\mathbf{2}$ that cannot be fitted are the first and the last, and it is assumed that the fitted protonation constants correspond to $\mathrm{pK}_{2-4}$.

Due to their structural similarities, the titrations involving dinucleating 5 and 6 could be fitted using the same model, with only slight differences in the $\mathrm{pK}_{\mathrm{a}}$ values obtained. The model involved six protonations of the free ligand and one complex protonation. Both ligands contain ten possible sites of protonation, but all ten could not be fitted under the conditions investigated. It is probable that the protonation constants of each individual macrocycle are similar to those of the parent monomeric ligand, suggesting that the protonations that cannot be fitted are the first and the last three. Thus it is assumed that the fitted protonation constants correspond to $\mathrm{pK}_{2-7}$. The titration and species distribution curves for 5 and 6 were very similar. The two macrocycles of the dimeric ligands are identical and, as such, it is expected that they should have very similar acid 
dissociation constants, perturbed only by subtle different electronic effects between ortho- and parasubsitution and associated spatial constraints for the tethered macrocycles. The macrocyclic moiety is also identical to that of 1 , the parent monomer. Consequently, it is not unreasonable to expect that each dimer would have two $\mathrm{pK}_{\mathrm{a}}$ values that are similar to one of the $\mathrm{pK}_{\mathrm{a}}$ values of 1 . The fact that the $\mathrm{pK}_{\mathrm{a}}$ values for the dimers are not significantly different to those of the monomer suggests that the two macrocycles of the dimer are removed sufficiently that they have limited interaction. Despite the obvious similarities in $\mathrm{pK}_{\mathrm{a}}$ values, small differences can be observed, reflecting both electronic influences of substituents and differing numbers of potential protonation sites. Different opportunities for the pendant group to participate in hydrogen-bonding interactions with the intra-ring protons are presumably partly responsible for the differences observed. The macrocycles containing an aromatic pendant arm have initial $\mathrm{pK}_{\mathrm{a}}$ values that are more basic than those without, as the aromatic group is electron withdrawing, thus increasing the basicity of the ligand.

Titrations of the copper complexes to determine $\mathrm{pK}_{\mathrm{a}}$ of pendant groups proved revealing, and the influence of coordination of the macrocycle on the $\mathrm{pK}_{\mathrm{a}}$ of the pendant has not been determined previously. The $\mathrm{pK}_{\mathrm{a}}$ value assigned to the pendant amine in the free ligand 1 is 5.67 , where the macrocycle retains two protons trapped within the macrocycle framework [57]. As such, it is more similar to a complex of a dipositive metal ion than would be the case were the cavity empty. Nevertheless, the $\mathrm{pK}_{\mathrm{a}}$ of the pendant in the copper complex of 1 is markedly lower at 4.13, which may relate to the partial involvement of the metal ion through coordination to the free amine in the aminium-amine equilibrium. The copper complex solution of $\mathbf{2 5}$, where no pendant is in place, showed no protonation phenomena. This is expected, as in order to protonate a nitrogen of this complex, one of the strong macrocyclic $\mathrm{Cu}-\mathrm{N}$ bonds would need to be broken, not observed nor anticipated under these conditions. It should be noted that no protonation was also observed for 26 , which carries a single carboxylate pendant [58]. The $\mathrm{pK}_{\mathrm{a}}$ of the carboxylate group is probably too low to be determined under these conditions, and a value of $\leq 3$ was suggested, supported by the known low $\mathrm{pK}_{\mathrm{a}}$ values of carboxylic acids $\alpha$ to an amine, coupled with the influence of formation of a stable six-membered chelate ring between the copper centre and the carboxylate pendant arm, which would prohibit protonation. In contrast to the results seen for 1 , the $\mathrm{pK}_{\mathrm{a}}$ of the pendant arm of the copper complex of 2 (7.05) is significantly higher than that of the free ligand (4.66). In addition, the spectrum of the complex does not change with $\mathrm{pH}$, suggesting that the pendant arm does not coordinate strongly in aqueous solution to the copper centre when unprotonated. The higher $\mathrm{pK}_{\mathrm{a}}$ of the pendant arm within the complex is possibly due to the hydrogen bonding between the uncomplexed diprotonated macrocycle and the unprotonated pendant amine, which stabilises the unprotonated amine and thus lowers the $\mathrm{pK}_{\mathrm{a}}$ in the free ligand. Such hydrogen bonding is not possible in the complex, and consequently the $\mathrm{pK}_{\mathrm{a}}$ is higher. Only a single $\mathrm{pK}_{\mathrm{a}}$ value could be determined for both dimeric complexes. These values are very similar to that of 1 , which is not unexpected given the structural similarities between the complexes. As the first $\mathrm{pK}_{\mathrm{ML}}$ is $\sim 4$, and a second protonation of the $-\mathrm{NH}-\mathrm{CH}_{2}-\mathrm{C}_{6} \mathrm{H}_{4}-\mathrm{CH}_{2}-\mathrm{NH}$ - core would be more difficult, this would lead to a substantially lower second value that would be outside the range determinable by the titration.

\section{DNA Clcavage}

Although the $\mathrm{Cu}^{2+}{ }_{\text {aq }}$ ion is not effective as a promoter of hydrolytic DNA cleavage, polyamine complexes of $\mathrm{Cu}$ (II) can show considerable activity. Reaction of metal(II) complexes and plasmid DNA where the complete disappearance of form I (supercoiled) to form II (circular) and in some cases form III (linear) plasmid DNA is observed in a period of less than 24 hours under standard conditions (as outlined in the Experimental) is indicative of an active promoter of DNA cleavage, given the inertness of the phosphodiester bonds in the absence of promoted cleavage (half-life for DNA of $\sim 130000$ years at $25^{\circ} \mathrm{C}$ 
and neutral $\mathrm{pH}$ [59]). The general absence in the compounds of mainly aliphatic ligands that we have studied of any measurable effects on activity from removal of oxygen or addition of radical scavengers (e.g. ethanol or DMSO) suggests there is no significant role for coordinated peroxide or diffusible hydroxide radicals in cleavage, and support the view of these compounds as dominantly agents promoting hydrolytic cleavage. The simple monomer $\left[\mathrm{Cu}(\mathbf{1 7})\left(\mathrm{OH}_{2}\right)_{2}\right]^{2+}(\mathbf{1 7}=$ tach $=$ cyclohexane-1,3,5triamine) has been shown earlier to be an efficient reagent for DNA hydrolytic cleavage $[60,61]$, and activity is assigned to the availability of two labile cisdisposed water molecules that can bind DNA via a phosphodiester oxygen atom and supply the other adjacent water molecule (or more properly a hydroxide ion, as a result of deprotonation due to the low $\mathrm{pK}_{\mathrm{a}}$ of coordinated water molecules) as the nucleophile. Of course, availability of cis-disposed water groups is no guarantee of activity. Our examination here of the triamine ligands $17-20$ as $1: 1 \mathrm{Cu}(\mathrm{II}): \mathrm{L}$ complexes defined a cleavage rate for 17 of $3.2 \times 10^{-5} \mathrm{~s}^{-1}$ (at $0.75 \mathrm{mM}, 37^{\circ} \mathrm{C}, \mathrm{pH} 7.6$ ), whereas $18\left(5 \times 10^{-6} \mathrm{~s}^{-1}\right)$ and $20\left(3.5 \times 10^{-6} \mathrm{~s}^{-1}\right)$ are less effective and 19 (the $\mathrm{N}$-methylated analogue of 18) showed no measurable activity at all under the same conditions. Activity is presumably related to a range of factors including complex coordination geometry, shape and steric effects associated with the spectator polyamine ligands, metal-donor bond lengths and angles, acidity of coordinated water groups and rates of exchange of coordinated water.

If activity relies on two water molecules being adjacent in the coordination sphere, then systems that cannot supply two cis-disposed water molecules, or else do not provide sufficient site lability, should prove inactive. This has been probed recently with examination of copper(II) complexes of acyclic polyamines where four nitrogen donors occupy the axial sites around the metal ion [62]. These show sharply reduced activity compared with $\left[\mathrm{Cu}(17)\left(\mathrm{OH}_{2}\right)_{2}\right]^{2+}$, but the activity is not completely turned off. This has been assigned to the capacity of the acyclic systems to undergo some dissociation of a chelate arm, leading to a pair of cis-disposed sites.

The type of ring-opening reaction described above is removed by ligand cyclisation, and macrocyclic tetraamines are anticipated to show no appreciable activity as they commonly bind with the four amines and metal ion in the same plane, with only trans axial sites remaining. However, saturated macrocycles can fold, albeit in a relatively high energy process, into cis geometries around a pseudo-octahedral complex centre, leading to a pair of cis-disposed sites. Macrocycle ring rigidity and hence the preference for trans geometries upon coordination can be increased by inclusion of aromatic groups in the ring. However, complexes of macrocycles with a completely

\section{$\begin{array}{llllllllllllllllllll}1 & 2 & 3 & 4 & 5 & 6 & 7 & 8 & 9 & 10 & 11 & 12 & 13 & 14 & 15 & 16 & 17 & 18 & 19 & 20\end{array}$}

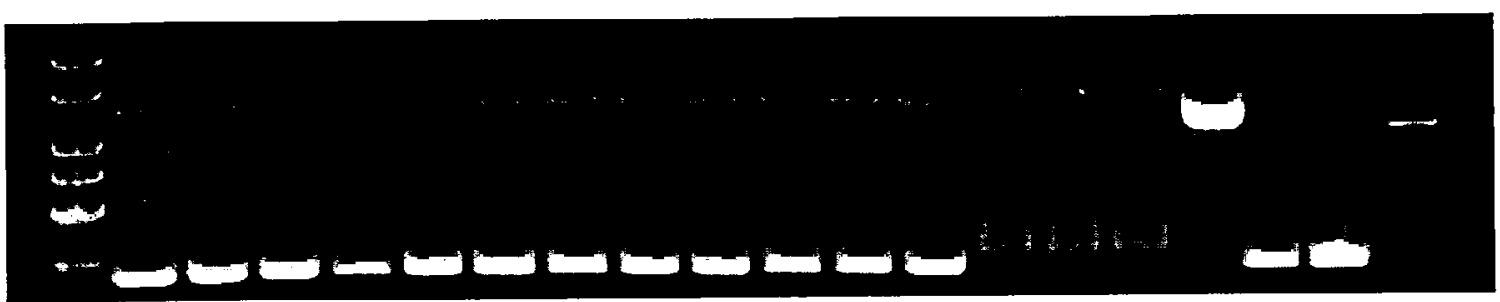

FIGURE 4

Gel electrophoresis of plasmid DNA with some copper(II) complexes. Triplicates for monomer complexes $\mathrm{Cu}(1)$ (lanes 2-4), Cu(2) (lanes 57) and dimer complexes $\mathrm{Cu}_{2}(5)$ (lanes 8-10) and $\mathrm{Cu}_{2}(6)$ (lanes 11-13). The monomeric $\mathrm{Cu}(4)$ (lanes 14-16) also shows no cleavage, but a clear shift in $R_{f}$ values. A molecular marker (lane 1), positive control (lane 17), water blank (lane 18, 19) and linear DNA (lane 20) are also present. 
aromatic ring may stabilize radicals and thus promote known non-hydrolytic DNA cleavage pathways. Consequently, partial aromatic character may be preferable for probing the influence of rigidity on hydrolytic cleavage. Here, both ligands based on the saturated cyclam framework or on the 15-membered ring analogue and a series of tetraamine isocyclam macrocycles incorporating one pyridine group in the ring have been examined. Apart from the parent system, ligands with $\mathrm{N}$-based substituents, including some with potentially coordinating groups, have been included for analysis.

The pyridine-containing tetraamine 7 and analogues are known to form simple 1:1 complexes with a range of metal ions where the metal binds the four nitrogen donors tightly [17-21]. X-ray crystal structures of $\mathrm{Ni}(\mathrm{II})$ complexes of 8 and the $\mathrm{N}$-methylated analogue of 7 have been reported, where the metal is in a square pyramidal environment, with a folded macrocycle and a chloride ion at one comer of the basal square. $\mathrm{As} \mathrm{Cu}$ (II) is also content with five-coordination, complexes of 7 $\mathbf{9}$ are likely to form similar square-pyramidal structures, where two free adjacent coordination sites are not available. The $\mathrm{Cu}(\mathrm{II})$ complexes of 7 and of the $\mathrm{N}$ substituted dibenzyl (8) and tribenzyl (9) analogues show no measurable DNA cleavage capacity, consistent with expectations discussed above. Notably, the less labile $\mathrm{Ni}(\mathrm{II})$ and more labile $\mathrm{Zn}$ (II) complexes of these ligands also show no activity.

Examples where one of the benzene groups is replaced by a potentially coordinating pyridine group (10), propionate group (11) or (1-pyrrolidinyl)ethyl group (13) have also been probed [17-21]. Likewise, the introduction of two potentially coordinating pendants via two (1-pyrazolyl)methyl groups (12), has been examined. The crystal structure of $\mathbf{1 3}$ as its $\mathrm{Ni}(\mathrm{II})$ complex shows a square pyramidal geometry with the macrocycle at the base of the pyramid and the pyrrolidinyl group at the apex. The analogue of 7 with two 2-methylpyridine pendants shows the macrocycle folded around the metal centre and both pendant groups coordinated. It is likely that the pendant groups bind in the complexes examined here, limiting available sites for water binding. If this occurs, then no activity is expected for complexes of
$10-13$ as no adjacent pair of coordination sites are vacant; even with six-coordination, two vacant sites are not present if pendants bind. Indeed, no activity results for all except the $\mathrm{Cu}(\mathrm{II})$ complex of $\mathbf{1 3}$, which displays some limited activity (Figure 4). The source of this activity deserves consideration. The coordinating groups on the pendant arms of 10, 11 and 12 all have acid dissociation constants below 5.5 $(5.4,2.5$ and 3.7 respectively) $[63,64]$, and hence in solution at physiological $\mathrm{pH}$ will not be protonated and thus able to bind, as found in solid state structures. The pyrrolidine group present in 13, however, has a $\mathrm{pK}_{\mathrm{a}}$ of 11.3 [63], and although basic groups attached to a macrocycle have been observed to exhibit a somewhat lower $\mathrm{pK}_{\mathrm{a}}$ than for the free base, it is unlikely that the $\mathrm{pK}_{\mathrm{a}}$ will fall below 8 . Consequently, this group would be protonated and not bound at physiological $\mathrm{pH}$. Further, it is possible that the protonated pyrrolidine group may bind electrostatically to the anionic phosphate groups of DNA, locating the complex close to the DNA backbone and orientating the water molecule on the metal sufficiently to initiate hydrolysis. Whereas some activity is seen for the $\mathrm{Cu}$ (II) complex, the $\mathrm{Ni}$ (II) complex is inactive. This is consistent with a requirement for a coordinated hydroxide as attacking nucleophile, as the $\mathrm{pK}_{\mathrm{a}}$ of coordinated water on $\mathrm{Ni}$ (II) (10.5) is significantly higher than that on $\mathrm{Cu}$ (II) (8.0) [65], so that a much lower percentage of the Ni(II) complex would be active under the reaction conditions $(\mathrm{pH} 7.6)$, irrespective of other considerations.

The $\mathrm{Cu}$ (II) complex of the 14-membered tetraamine macrocycle cyclam (14) and its $\mathrm{N}$ substituted tetrabenzyl analogue (15) are inactive. Complexes of cyclam typically exist with the metal ion in the plane of the four nitrogen donors, with folded geometries only supported for cyclam when an addition chelating ligand is bound. Consequently, cisdisposed coordination sites are not anticipated, consistent with lack of activity. When the cyclam framework is amended by inclusion of C-pendant amine groups, as in trans-diammac (23), some modest promotion of cleavage is detected $\left(\mathrm{k} \sim 10^{-6} \mathrm{~s}^{-1}\right)$. Where pendant groups carrying potential donor groups have 
been introduced, they can compete with water groups for 'vacant' axial sites on the metal ion (and hexacoordination of diammac is known in the solid state [36]), in principle limiting further the potential value of the mononuclear complexes as artificial nucleases. However, steric strain in binding the Cpendant amines axially to the Jahn-Teller elongated $\mathrm{Cu}$ (II) limits their coordination, allowing a different role for the free amine pendants through location of the complex adjacent to the phosphodiester backbone of DNA via hydrogen bonding, somewhat like the mechanism proposed with 13 above, producing modest promotion of cleavage. Notably, however, the 15-membered tetraamine macrocycle carrying only one pendant amine (1) and its benzylated pendant analogue (2) exhibit no measurable promotion, suggesting that other subtle effects influence the outcome, which is not sufficient to be of practicable value in any case. Related 14-membered tetraaaza cyclam-like macrocycles that have $\mathrm{N}$-for-C substitution in the central site of each propane chain and carry 4-methylpyridine, propionitrile ot hydroxyethane pendants at those sites have been examined for their cleavage of plasmid DNA [66]. These mononuclear macrocyclic complexes also exhibit no promotion of hydrolytic cleavage, and only catalyze cleavage in the presence of $\mathrm{H}_{2} \mathrm{O}_{2}$ or 2-mercaptoethanol, when radical mechanisms operate. It is only when there are sufficient coordinating pendant groups attached to support coordination of two metal ions, as for 16, that significant hydrolytic activity can result, but through a different mechanism to that available for mononuclear macrocyclic systems.

The recent observation that the monomer complex $[\mathrm{Cu}(27)]^{2+}$ is inactive whereas the dimer analogue $\left[\mathrm{Cu}_{2}(28)\right]^{4+}$ is highly efficient as a DNA cleavage agent has highlighted the potential for dinuclear systems to act as effective artificial nucleases [67]. Systems featuring two metal centres within the one ligand may be more effective models of nucleases, where multi-metal environments are commonly met. A range of dinucleating topologies have been described and examples synthesised, and it is of interest to examine how relative disposition of the two metal ions and flexibility of complex systems can influence the capacity of complexes to act as artificial nucleases. It is anticipated that the two metal centres must be capable of each directing a coordination site towards the same phosphodiester linkage for effective cleavage; this may be limited by ligand rigidity or, conversely, too great a flexibility and or separation of the centres. A number of ligand systems have been examined here to probe this effect.

The relatively flexible dinucleating ligands 5 and $\mathbf{6}$, as dicopper(II) complexes, exhibit only a very limited acceleration of hydrolytic DNA cleavage, with less than $10 \%$ of the single strand form appearing after 24 hrs. Although the copper(II) complex of the mononuclear analogue $\mathbf{2}$ is totally inactive under comparable conditions, the enhancement resulting from linking the two copper centres together is not a significant effect in this case. This may relate to the flexibility of the ligand through the relatively long linker, which does not confine the two metal centres to be closely adjacent. Indeed, placing two like-charged centres adjacent is disfavoured and thus not supportive of a concerted mechanism. However, it is notable that separate kinetic and thermodynamic studies imply a coordinating role for the pendant amine, which would limit sites for water coordination and thus the supply of appropriately oriented coordination sites and coordinated nucleophiles.

Ligands that enforce two metals to lie closely adjacent may offer greater promise, and subsequently the two-compartment macrocycles 21 and 22 were examined. These are known to form dimetal(II) complexes $($ metal $=\mathrm{Cu}, \mathrm{Ni}, \mathrm{Pd})$ where the two metal centres are required to be close together, each sharing two cis-disposed bridging $\mathrm{O}^{-}$or $\mathrm{S}^{-}$donors; several examples have been characterised by $\mathrm{X}$-ray crystal structures $[29,30]$. The dicopper(II) complexes, at least in the solid state, carry water or anion groups in axial sites, providing the potential for two adjacent coordinated water molecules in adjacent axial sites in solution. The dipalladium(II) complex exhibits square planar geometry around the metal ions, and thus without labile axial sites should be entirely inactive, as found here experimentally. It was anticipated that the dicopper(II) complex, where axial groups bind, could be highly active; however, this proved not to be 


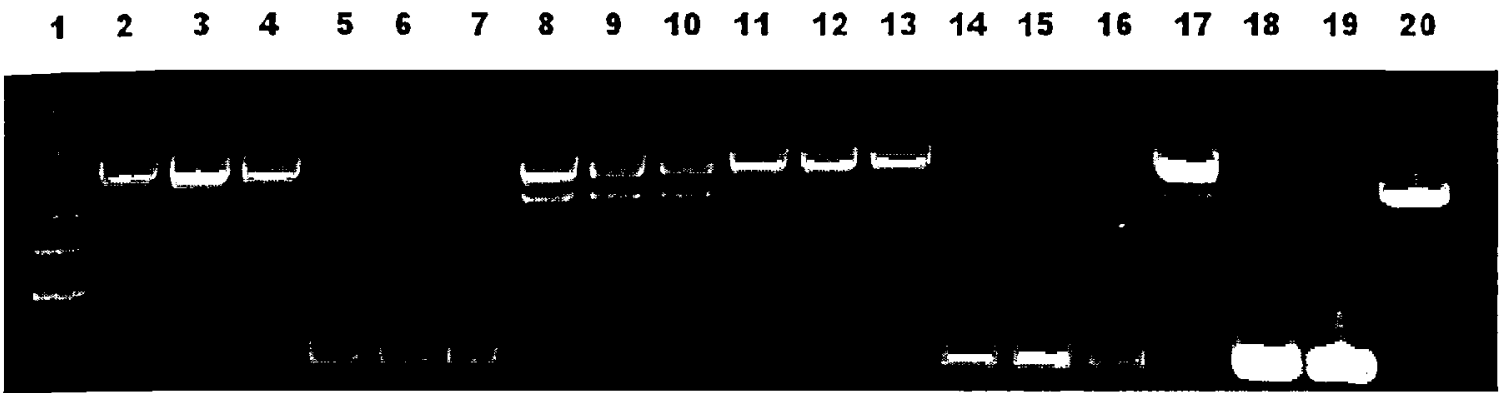

\section{FIGURE 5}

Gel electrophoresis of plasmid DNA with various complexes. Triplicates for monomers $\mathrm{Cu}(11)$ (lanes 5-7), $\mathrm{Cu}(13)$ (lanes $11-13)$ and $\mathrm{Ni}(13)$ (lanes 14-16), showing that $\mathrm{Cu}(13)$ alone promotes single cleavage to circular DNA. Triplicates for the hydrolytically very active 1:1 and 2:1 Cu:16 systems (lanes 2-4 and 8-10 respectively). A molecular marker (lane 1), positive control (lane 17), water blank (lane 18, 19) and linear DNA (lane 20) are also present.

the case, with very modest cleavage ( $<10 \%$ after 24 hrs) found, while the more inert nickel(II) system showed no activity. In this case, the molecule may be too rigid. The two metal centres, and hence axial sites, are $-3.5 \AA$ apart. The crystal structure of the $\mathrm{Cu}_{2}(21)$ compartment complex, amended to append a coordination $\left[\mathrm{PO}_{4} \mathrm{H}_{2}\right]^{-}$ group in an optimised position was modelled with the $\mathrm{MM}+$ forcefield, and the $\mathrm{O}$ of the adjacent water molecule is located $3.80 \AA$ away from the bound P, very similar to the situation modelled in the active monomer $\left[\mathrm{Cu}(17)(\mathrm{OH})\left(\mathrm{OPO}_{3} \mathrm{H}_{2}\right)\right]^{-}$above; thus separation alone does not appear to be an issue. Limited flexibility may mean that coordination of a phosphodiester group at one site does not place the other axial site in an appropriate disposition for effective nucleophilic attack at the phosphorous centre, that is there is inappropriate orbital steering by the metal assembly. Thus, in this case ligand rigidity may act against effective cleavage; close placement of reaction sites alone is not sufficient. Even the dicopper(II) complex of the acyclic analogue 29 offers no activity, since the metal ion environment is identical to those in the macrocycles. Although 27 and 28 offer comparable cis- $\mathrm{N}_{2} \mathrm{~S}_{2}$ coordination of the copper(II) ions, the highly active dicopper(II) complex of $\mathbf{2 8}$ offers greater flexibility as a result of the spacer group, since methylene groups attached to the central aromatic ring allow greater conformational freedom than is present in 22 .
Another dinucleating topology that provides for close approach of metal centres involves employing a macrocyclic base and four coordinating pendant arms. Two metal ions can be accommodated, one each by pairs of macrocyclic and acyclic nitrogens. Although there is some flexibility as a result of the allowed motion of the pendant arms, this is moderated by the macrocyclic framework. More importantly, when two metal ions are bound, it is particularly common for the dinuclear complex to be stabilised by a bridging anion that links the two metal centres directly, providing for close approach of the metal centres and a relatively rigid structure. This is illustrated for the hydroxy-bridged dicopper(II) complex examined here in Figure 5. Whereas the parent macrocycle (14) and the N-tetrabenzyl substituted macrocycle (15), which each bind just one copper(II) ion, are inactive, the hydroxy-bridged dicopper complex of 16 is very active. Sequential single and double strand cleavage results, with the second process approximately 40 fold slower, as apparent in the gels (Figure 6). Activity for the first cleavage $\left(k \sim 1.2 \times 10^{-4} \mathrm{~s}^{-1}\right.$ with 8 $\left.\times 10^{-4} \mathrm{M}[\mathrm{Cu}], 37^{\circ} \mathrm{C}, \mathrm{pH} 7.6\right)$ is slightly lower than that of the benchmark copper(II) complex of $17(\mathrm{k}-1.5$ $\left.\times 10^{-4} \mathrm{~s}^{-1}\right)$ under the same conditions, whereas for the second cleavage it is clearly superior $\left(\mathrm{k} \sim 3.5 \times 10^{-6} \mathrm{~s}^{-1}\right.$ versus $\left.\mathrm{k} \sim 1.0 \times 10^{-6} \mathrm{~s}^{-1}\right)$. The hydroxide that bridges the two copper centres is a highly effective 


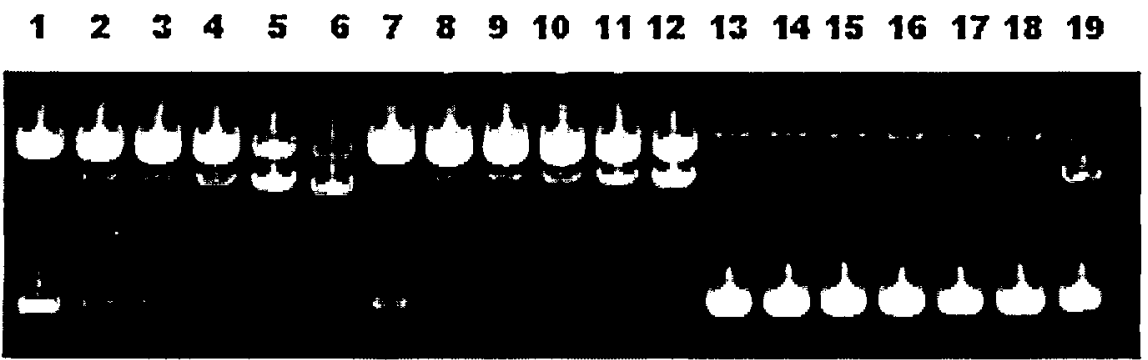

\section{FIGURE 6}

Time dependence study by electrophoresis gel of the cleavage of plasmid DNA by active dimer $\mathrm{Cu}_{2}(16)$ (lanes 1-6) and active monomer $\mathrm{Cu}(11)$ (lanes 7-12), along with a water blank (lanes 13-18) and a comparison mixture of helical, circular and linear DNA (lane 19). For each set of lanes, cleavage times (at $37^{\circ} \mathrm{C}$ ) are (from left to right) $3,6,12,24,48$ and 96 hours.

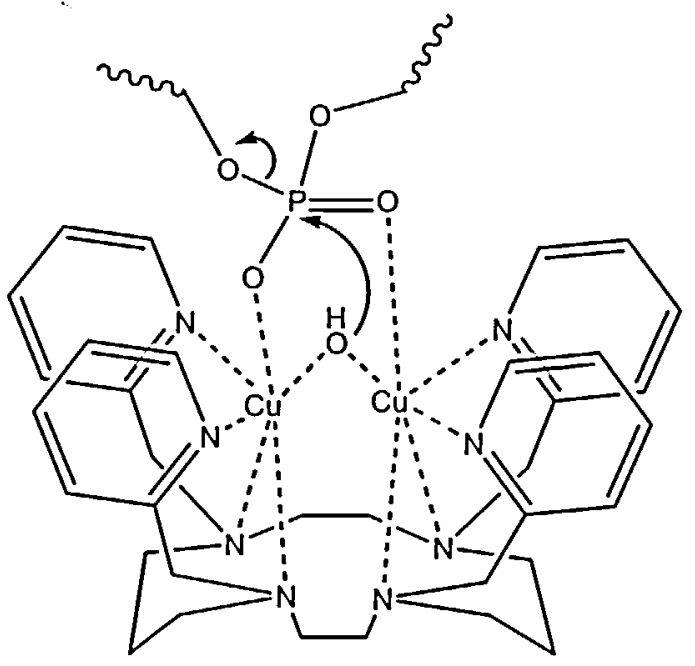

FIGURE 7

Proposed intermediate in the promoted cleavage of DNA by $\mathrm{Cu}_{2}(16)$.

nucleophile. At first inspection of the solid state structure [68], available adjacent sites for binding and nucleophile supply are not immediately apparent. However, solution structures need not reflect solid state structures fully. It is likely that the dinuclear complex straddles the phosphate backbone, with the flexible pyridine arms able to relocate partially on a copper centre to provide for phosphodiester coordination while retaining the efficient bridged hydroxide as attacking group (Figure 7). The ability of an oxygen-rich anion to bridge the two copper centres has been demonstrated in the solid state for nitrate, which binds each copper centre through a different oxygen atom [68]. Approach to the backbone would be promoted by the cationic nature of the complex, with the close location of two dipositive metal centres enhancing the interaction and orientation. The complex may offer the proper balance of rigidity and flexibility to strongly promote cleavage. Previously, the acetate-bridged dinuclear copper(II) complex of $\mathbf{3 0}$, which has the deprotonated alcohol bridging the copper centres as well as an acetate group, has been shown to promote DNA hydrolytic cleavage, with a rate constant of $6.7 \times 10^{-5}$ $\mathrm{s}^{-1}$ at higher temperature $\left(50^{\circ} \mathrm{C}, \mathrm{pH} 6.6\right)$ [69]; this is slower than the compound examined here after adjusting for temperature differences, possibly by at least an order of magnitude. The lower activity for the dicopper(II) complex of $\mathbf{3 0}$ may relate to both its overall lower charge and absence of a bridging hydroxide nucleophile; instead it carries two water groups, one on each copper centre.

Further, cleavage by these types of dinuclear complexes and indeed the other types examined may exhibit site selectivity with nucleic acids. For small coordination compounds that act hydrolytically as chemical nucleases, DNA site selectivity is left relatively unreported in the literature $[59,70,71]$, 
although saturated polydentate complexes generally, while not ideal for high DNA cleavage activity, may be appropriate for interaction with DNA that leads to specific binding or cleavage [72]. There are recent examples that present site recognition of nucleic acids for other types of metal complexes, such as metallointercalators [73, 74], multi-united agents (antisense type agents for example) [75-78], inert metal, base binders (cisplatin) [79] or for RNA targets [80, 81]. The lack of information for small molecule nucleases is partly due to experimental demands, as more sophisticated biological experiments are required to detect site recognition. In one such landmark study, diand tri-copper(II) complexes of pyridine-rich polynucleating ligands have been shown recently to promote in DNA both efficient and specific strand scission [82]. We have examined the basis for selectivity via a molecular mechanics study of the docking of mono- and dicopper(II) complexes with DNA, modelled by variation of DNA bases at a single site a double stranded 20-mer-olignucleotide. Interaction and binding energy trends of the olignucleotide with complexes suggest a preference for particularly the asterisked site in $\mathrm{ApTp}^{*} \mathrm{Ap}$, as opposed to a ApApAp sequence. This work, along with experimental further studies of dinuclear systems of different geometry, will be described elsewhere. What is evident from the present study is that, even with dinuclear systems, the correct balance of flexibility, rigidity and overall stereochemistry is essential for activity as an artificial nuclease. Labile metal centres that share a nucleophile offer particular promise.

\section{Acknowledgments}

Support of the Australian Research Council for this project is acknowledged. The assistance of Dr Jeffrey Harmer (ETH, Zurich, Switzerland) in recording ESR spectra is gratefully acknowledged.

\section{REFERENCES}

[1] A. Jeltsch, C. Wenz, W. Wende, U. Selent and A. Pingoud, Trends Biotechnol. 1996, 14, 235-238.

[2] D. S. Sigman, A. Mazumder and D. M. Perrin, Chem. Rev. 1993, 93, 2295-2316.
[3] L. Zheng, M. Li, J. Shan, R. Krishnamoorthi and B. Shen, Biochemistry 2002, 41, 10323-10331.

[4] G. R. Martinez, A. P. M. Loureiro, S. A. Marques, S, Miyamoto, L. F. Yamaguchi, J. Onuki, E. A. Almeida, C. C. M. Garcia, L. F. Barbosa, M. H. G. Medeiros and P. Di Mascio, Mutation Res. 2003, 544, 115-127.

[5] T. K. Chiu and R. E. Dickerson, J. Molec. Biol. 2000, 301, 915-945.

[6] L. Zheng, L. Mei, J. Shan, R. Krishnamoorthiand B. Shen, Biochem. 2002, 41, 10323-10331.

[7] C. Liu, M. Wang, T. Zhang and H. Sun, Coord. Chem. Rev. 2004, 248, 147-168.

[8] O. Iranzo, T. Elmer, J. P. Richard and J. R. Morrow, Inorg. Chem. 2003, 42, 7737-7746.

[9] B. N. Trawick, A. T. Daniher and J. K. Bashkin, Chem. Rev. 1998, 98, 939-960.

[10] S. Kuusela and H. Lonnberg, Metal Ions Biol. Systems 1996, 32 271-300.

[11] L. M. Rossi, A. Nevers, R. Horner, H. Terenzi, B. Szpoganicz and J. Sugai, Inorg. Chim. Acta 2002, 337, 366-370.

[12] M. Scarpellini, A. Nevers, R. Hörner, A. J. Bortoluzzi, B. Szpoganics, C. Zucco, R. A. Nome Silva, V. Drago, A. S. Mangrich, W. A. Ortiz, W. A. C. Passos, M. C. B. de Oliveira and $\mathrm{H}$. Terenzi, Inorg. Chem, 2003, 42, 8353-8365.

[13] C. Sissi, F. Mancin, M. Gatos, M. Palumbo, P. Tecilla and U. Tonellato, Inorg. Chem. 2005, 44, 2310-2317.

[14] J. H. Kim, S. H. Kim, Chem. Letts. 2003, 32, 490-491.

[15] G. A. Lawrance and M. A. O'Leary, Polyhedron 1987, 6, 1291-1294.

[16] A. D. Hamilton, H.-D. Rubin and A. B. Bocarsly, J. Am. Chem. Soc. 1984, 106, 7255-7257.

[17] N. W. Alcock, K. P. Balakrishnan and P. Moore, J. Chem. Soc., Chem. Commun. 1985, 1731-1733.

[18] N. W. Alcock, K. P. Balakrishnan, A. Berry, P. Moore and C. J. Reader, J. Chem. Soc., Dalton Trans. 1988, 1089-1093.

[19] N. W. Alcock, K. P. Balakrishnan and P. Moore, J. Chem. Soc., Dalton Trans. 1986, 2743-1745.

[20] N. W. Alcock, K. P. Balakrishnan, P. Moore and H. A. A. Omar, J. Chem. Soc., Dalton Trans. 1987, 545-550.

[21] K. P. Balakrishnan, H. A. A. Omar, P. Mloore, N. W. Alcock and G. A. Pike, J. Chem. Soc., Dalton Trans. 1990, 2965-2969.

[22] H. Stetter and K. H. Mayer, Chem. Ber. 1961, 94, 1555-1562.

[23] Y. Dong, G. A. Lawrance, L. F. Lindoy and P. Turner, Dalton Trans. 2003, 1567-1576.

[24] N. W. Alcock, K. P. Balakrishnan, P. Karapuli and P. Moore, J. Chem. Soc., Dalton Trans. 1986, 1743-1745.

[25] F. Lions and K. V. Martin, J. Am. Chem. Soc. 1957, 79, $1572-$ 1575.

[26] H. Koyama and T. Yoshino, Bull. Chem. Soc. Jpn 1972, 45, 481-48.4.

[27] K. Wieghardt, P. Chaudhuir, B. Nuber and J. Weiss, Inorg. Chem. 1982, 21, 3086-3090.

[28] P. Comba, G. N. Deluliis, G. A. Lawrance, S. M, Luther, M. Maeder, A. L. Nolan, M. J. Robertson and P. Turner, Dallon Trans. 2003, 2188-2193. 
[29] G. A. Lawrance, T. M. Manning, M. A. O'Leary, B. W. Skelton and A. H. White, J. Chem. Soc., Dalton Trans. 1990, 2491-2495.

[30] P. Comba, G. A. Lawrance, T. M. Manning, A. Markiewicz, K. S. Murray, M. A. O'Leary, B. W. Skelton and A. H. White, Alust. J. Chem. 1990, 43, 69-78.

[31] P. Comba, N. F. Curtis, G. A. Lawrance, A. M. Sargeson, B. W. Skelton and A. H. White, Inorg. Chem. 1986, 25, 4260-4267.

[32] J. F. Sambrook and D. W. Russell, Molecular Cloning: A Laboratory Manual, $3^{\text {rd }}$ ed., 2000, Cold Spring Harbor Laboratory Press, Plainview, NY.

[33] N. Horn, G. Budahazi, and M. Marquet, Vical Incorporated, USA, patent application.

[34] Hyperchem; Hypercube, Inc: $1115 \mathrm{NW}$ 4th Street Gainesville, Florida 32601, USA.

[35] P. Comba and T. W. Hambley, Molecular Modeling of Inorganic Compounds, $2^{\text {nd }}$ ed., 2000, Wiley-VCH, Weinheim.

[36] P.V. Bernhardt and G. A. Lawrance, Coord. Chem. Rev. 1990, 93, 297-343.

[37] G. A. Lawrance, M. Maeder and E. N. Wilkes, Rev. Inorg. Chen. 1993, 13, 199-232.

[38] G. A. Lawrance, M. Maeder, M. Napitupulu, A. L. Nolan, M. Rossignoli, V. Tiwow and P. Turner, Inorg. Chim. Acta 2005, 358, 3227-3235.

[39] P. V. Bernhardt an E. H. Hayes, Inorg. Chem. 2002, 41, $2892-$ 2902.

[40] P. V. Bernhardt, E. G. Moore, and M. J. Riley, Inorg. Chem. $2002,41,3025-3031$.

[4I] R. F. Borch, and H. D. Durst, J. Am. Chem. Soc. 1969, 91, 3996-3997.

[42] A. Bayada, G. A. Lawrance, M. Maeder, and M. A. O'Leary, J. Chem. Soc., Dalton Trans. 1994, 3107-31I1.

[43] R. F. Borch, M. D. Bernstein, and H. D. Durst, J. Am. Chem. Soc. 1971, 93, 2897-2904.

[44] L. Colombo, M. Di Giacomo, V. Vinci, M. Colombo, L. Mazoni and C. Scolastico, Tetrahedron 2003, 59, 4501-4513.

[45] S. Monge, S. Sélambarom, J. P. Roque and A. Pavia, Tetrahedron 2001, 57, 9979-9987.

[46] J. A. O'Meara, N. Gardee, M. Jung, R. N. Ben and T. Durst, J. Org. Chem. 1998, 63, 3117-3119.

[47] (a) T. Sawada, K. Fukumara and H. Saturai, Chem. Pharm. Bull. 1996, 44, 1009-1016. (b) P. Comba, N. F. Curtis, G. A. Lawrance, M. A. O'Leary, B. W. Skelton and A. H. White, J. Chem. Soc., Dalton Trans. 1988, 2145-2152.

[48] P. V. Bernhardt, P. Comba, L. R. Gahan, and G. A. Lawrance, Aust. J. Chem. 1990, 43, 2035-2044.

[49] P. V. Bemhardt, J. Y. Kim, Y. Kim, Y. H. lee and S. Chow, $C$. R. Chinie 2005, 8, 211-214.

[50] L. Fabbrizzi and A. Poggi, J. Chem. Soc., Dalton Trans. 1984, 1495-1499.

[51] P. Zanello, R. Seeber, A. Cinquantini, G.-A. Mazzocchin and L. Fabbrizzi, J. Chem. Soc., Dalton Trans. 1982, 893-897.

[52] L. Fabbrizzi, A, Poggi and P. Zanello, J. Chem. Soc., Dalton Trans. 1983, 2191-2195.

[53] M. Rossignoli, C. C. Allen, T. W. Hambley, G. A. Lawrance and M. Maeder, Inorg. Chem. 1996, 35, 4861-4866.

[54] A. M. Bond, G. A. Lawrance, P. A. Lay and A. M. Sargeson, Inorg. Chem. 1983, 22, 2010-2021.
[55] R. M. Izatt, J. S. Bradshaw, S. A. Nielsen, J. D. Lamb and J. J. Christensen, Chem. Rev. 1985, 85, 271-339.

[56] R. M. Izatt, K. Pawlak, and J. S. Bradshaw, Chem. Rev. 199I, 91, 172I-2085.

[57] P. G. Lye, G. A. Lawrance, and M. Maeder, J. Chem. Soc., Dalton Trans. 2001, 2376-2382.

[58] N. McCann, doctoral dissertation, University of Newcastle, 2005.

[59] E. L. Hegg and J. N. Burstyn, Coord. Chem. Rev. 1998, 173. 133-165.

[60] T. Itoh, H. Hisada, T. Sumiya, M. Hosono, Y. Usui and Y. Fujii, Chem. Commun. 1997, 677-678.

[61] G. N. De Iuliis, doctoral dissertation, University of Newcastle, 2005.

[62] M. J. Robertson, G. N. De Iuliis, M. Maeder and G. A. Lawrance, Inorg. Chim. Acta 2004, 357, 557-570.

[63] S. Searles, M. Tamres, F. Block and L. A. Quarterman, J. Am. Chem. Soc. 1956, 78, 4917-4920.

[64] G. Aylward and T. Finday, SI Chemical Data, $3^{\text {rd }}$ ed., 1994, John Wiley \& Sons, Brisbane.

[65] C. F. Baes and R. E. Mesmer, The Hydrolysis of Cations, 1976, John Wiley \& Sons, NY.

[66] J. Liu, T. Zhang, T. Lu, L. Qu, H. Zhou, Q. Zhang and L. Ji, J. Inorg. Biochem. 2002, 91, 269-276.

[67] G. N. De Iuliis, G. A. Lawrance and S. Fieuw-Makaroff, Inorg. Chem. Commun. 2000, 3, 307-109.

[68] E. Asato, H. Toftlund, S. Kida, M. Mikuriya and K. S. Murray, Inorg. Chim. Acta 1989, 165, 207-214.

[69] L. M. Rossi, A. Neves, R. Hörner, H. Terenzi, B. Szpoganicz and J. Sugai, Inorg. Chim. Acta 2002, 337, 366-370.

[70] J. L. Czlapinski, and T. L. Sheppard, Abstr., 222nd ACS National Meeting, Chicago, IL, USA, 2001, ORGN-491.

[7I] E. Kikuta, R. Matsubara, N. Katsube, T. Koike, and E. Kimura, J. Inorg. Biochem. 2000, 82, 239-249.

[72] S. Moghaddas, P. Hendry, R. J. Geue, C. Qin, A. M. T. Bygott, A. M. Sargeson, and N. E. Dixon, J. Chem. Soc., Dalton Trans. 2000, 2085-2089.

[73] Proudfoot, E. M.; Mackay, J. P.; Karuso, P. Biochemistry $2001,40,4867-4878$.

[74] J. G. Collins, A. D. Sleeman, J. R. Aldrich-Wright, I Greguric and T. W. Hambley, Inorg. Chem. 1998, 37, 3133-3141.

[75] K. D. Copeland, M. P. Fitzsimons, R. P. Houser and J. K. Barton, Biochemistry 2002, 41, 343-356.

[76] N. Berthet, A. Boudali, J. F. Constant, J. L. Decout, M. Demeunynck, A. Fkyerat, A. J. Garcia, A. Laayoun, P. Michon and J. Lhomme, J. Mfolec. Recognition 1994, 7, 99-107.

[77] A. Fkyerat, M. Demeunynck, J. F. Constant, P. Michon and J. Lhomme, J. Am. Chem. Soc. 1993, 115, 9952-9959.

[78] T. Barr, S. Lim and S. Franklin, Abst., 55th ACS Southeast Regional Meeting, Atlanta, GA, USA, 2003, 1075.

[79] T. W. Hambley, J. Chem. Soc., Dalton Trans. 2001, 2711-2718.

[80] J. A. Cowan, Current Opinion Chem. Biol. 2001, 5, 634-642.

[81] J. R. Morrow, O. Iranzo, Current Opinion Chem. Biol. 2004, $8,192-200$.

[82] K. J. Humphreys, K. D. Karlin and S. E. Rokita, J. Am. Chem. Soc. 2002, 124, 6009-6019. 